Federal Reserve Bank of New York
Staff Reports

\title{
The Effect of State Pension Cut Legislation on Bank Values
}

\author{
Lee Cohen \\ Marcia Millon Cornette \\ Hamid Mehran \\ Hassan Tehranian
}

Staff Report No. 679

June 2014

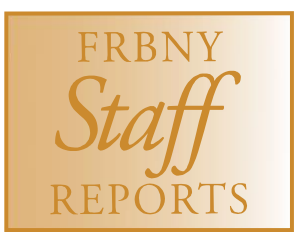

This paper presents preliminary findings and is being distributed to economists and other interested readers solely to stimulate discussion and elicit comments. The views expressed in this paper are those of the authors and are not necessarily reflective of views at the Federal Reserve Bank of New York or the Federal Reserve System. Any errors or omissions are the responsibility of the authors. 
The Effect of State Pension Cut Legislation on Bank Values

Lee Cohen, Marcia Millon Cornett, Hamid Mehran, and Hassan Tehranian

Federal Reserve Bank of New York Staff Reports, no. 679

June 2014

JEL classification: G11, G21, H72, H75

\begin{abstract}
This study provides an empirical analysis of the impact of Wisconsin and Ohio pension cut legislation on values of banks operating in Wisconsin and Ohio, banks operating in other states in which pension cut legislation was being considered as Wisconsin and Ohio went through its legislative process, and all publicly traded U.S. banks. We find that banks doing business in Wisconsin and Ohio experience positive (negative) stock price reactions to announcements that indicate an increased (a decreased) probability of pension cut legislation. The stock price reactions are positively related to the extent to which banks operate in Wisconsin and Ohio. Stock price reactions are rarely evident for banks in the other thirteen states that were considering pension cut legislation during the period of analysis. We also find municipal bond spreads tighten and bank credit supply increases with pension cut legislation. Overall, the findings suggest states' budget cuts affect bank values and credit supply through their municipal bond holdings.
\end{abstract}

Key words: financial institutions, municipal debt, public pensions

Cohen: University of Georgia (e-mail: leecohen@uga.edu). Cornett: Bentley University (e-mail: mcornette@bentley.edu). Mehran: Federal Reserve Bank of New York (e-mail: hamid.mehran@ny.frb.org). Tehranian: Boston College (e-mail: hassan.tehranian@bc.edu). The authors are grateful to Jim Booth, Ozgur Demirtas, Erik Gilje, Atul Gupta, Oguzhan Karakas, Darren Kisgen, Alan Marcus, Lindsay Mollineaux, Jim Musumeci, Jun Qian, Kristle Romero Cortés, Ronnie Sadka, Phil Strahan, and seminar participants at Boston College and Bentley University for their helpful comments. The views expressed in this paper are those of the authors and do not necessarily reflect the position of the Federal Reserve Bank of New York or the Federal Reserve System. 


\section{Introduction}

In the late 2000s, the U.S., and indeed the world, experienced the worst financial crisis since the 1930s and the Great Depression. As financial markets crumbled, jobs were lost and consumer spending slowed to a crawl. With the stagnation of consumer spending, tax revenues at the state levels experienced their steepest decline ever. Without these tax revenues, state budgets experienced massive deficits, for fiscal year 2011 budget deficits were estimated to exceed $\$ 100$ billion. ${ }^{1}$ Further, total outstanding state debt surpassed $\$ 4.2$ trillion in $2011 .{ }^{2}$ As large as they were, these budget deficits were overshadowed in size and scope by unfunded liabilities in state pension and health care systems for public employees. On average, in fiscal 2010, state pension plans had $75 \%$ of the assets needed to cover the long-term benefits owed to government workers. These fiscal 2010 deficits came after even greater deterioration immediately after the financial crisis. The average state pension fund was $78 \%$ funded in fiscal 2009 and $84 \%$ funded in fiscal $2008 .^{3}$

These pension funding gaps spurred many states to pursue changes to their retirement systems. Wisconsin and Ohio were the first states to see pension reform legislation signed into law (Wisconsin on March 11, 2011 and Ohio on March 31, 2011 ). By the end of March 2011, 13 other states had introduced legislation to reduce pension benefits. Associated with changes in pension benefits were changes in some collective bargaining rights of state employees: most government employees are union organized. Pension contributions and benefits are a part of the collective bargaining process between states and their unionized employees. Governors stated that they needed changes in collective bargaining rights in order to cut pension obligations. Thus,

\footnotetext{
${ }^{1}$ State Spending Restraint: An Analysis of the Path Not Taken, Mercatus Center at George Mason University, August 2010.

${ }^{2}$ State Budget Solutions, Real Solutions for Real Budget Problems, October 25, 2011.

${ }^{3}$ State Pension Plans Lose Ground, The Pew Center on States, April 2011.

${ }^{4}$ Although Ohio's reform was repealed in November 2011.
} 
these pension reform bills became synonymous with the abolition of public union bargaining rights and were termed "anti-union bills."

It is well documented that changes in regulations affect bank values. ${ }^{5}$ However, the impact of union activities on bank values has not been examined. Further, while many papers published in the economics literature examine unions and collective bargaining rights, there are very few papers that examine the impact of union bargaining rights on firm market value. Abowd (1989) finds that firm stock values move in the opposite direction of unexpected changes in union labor costs. Naiker and Navissi (2006) document that firms experience negative stock price effects in response to unionization. ${ }^{6}$

This study provides an empirical analysis of the impact of Wisconsin and Ohio pension cut legislation on values of banks operating in Wisconsin and Ohio, banks operating in other states in which anti-union measures were being considered as Wisconsin and Ohio went through its legislative process, and all other publicly traded U.S. banks. Legislative efforts aimed at reducing pension guarantees to public employees and at reducing public employees' collective bargaining rights were seen as a way of addressing states' huge budget deficits. Successful passage of this type of legislation arguably improves states' budget situations. Banks, in their role as lenders to municipalities, businesses, and consumers in the states, and as investors in municipal securities issued by the state, would directly feel the effects of improved budget conditions. However, at the same time it is possible that with the passage of this legislation,

\footnotetext{
${ }_{6}^{5}$ See Akhigbe and Martin (2006), Cornett et al. (2002) and Cornett et al. (1996) for just three examples.

6 A few other studies show relations between unionization and firm characteristics: Klasa, et al. (2009) and Matsa (2010) find that because maintaining high levels of corporate liquidity can encourage workers to raise their wage demands, as more unionized firms strategically hold less cash to gain bargaining advantages over labor unions and shelter corporate income from their demands. Faleye, et al. (2009) find that relative to other firms, labor-controlled publicly-traded firms deviate more from value maximization, invest less in long-term assets, take fewer risks, grow more slowly, create fewer new jobs, and exhibit lower labor and total factor productivity. Chen, et al. (2011) find that the cost of equity is significantly higher for firms in more unionized industries, while Chen et al. (2012) find that unionized firms have lower bond yields.
} 
banks would be hurt by lower spreads on the assets they hold. Thus, their profit margins would shrink with the passage of pension cut legislation. Hence, at face value it is not obvious in which way the prediction would go. Regardless, it is the case that banks would be affected by changes in the economic condition of the states in which they operate. Accordingly, banks should exhibit a stronger overall reaction to pension cut legislation than industrial firms in these states.

We find that banks doing business in Wisconsin and Ohio experience positive (negative) stock price reactions to announcements that indicate an increased (a decreased) probability of cut back legislation. The stock price reactions are positively related to the extent to which banks operate in Wisconsin and Ohio and to the percentage of municipal securities held in the portfolios of banks. Stock price reactions are rarely evident for banks in the other 13 states that were considering anti-union legislation during the period of analysis. Robustness tests indicate that Wisconsin and Ohio municipal bond spreads decreased (increased) significantly in reaction to announcements that indicate an increased (a decreased) probability of cut back legislation. Finally, we find that total lending by banks operating in Wisconsin increased over and after the period in which pension cut legislation was enacted, while total lending by banks operating in Ohio decreased over and after the period in which anti-union legislation was enacted and, eventually, overturned.

Our results complement Abowd and Lemeaux (1993), who exploit exogeneous shocks to firms' product markets to isolate the impact of firms' financial situations on union wage bargaining power. Just as their paper addresses endogeniety in the relationship between profitability and negotiated wages, we exploit exogeneous variation in union bargaining power, which allows us to highlight the other side of the reverse causality effect: union wage bargaining power can impact financial situations, particularly through the banking channel. 
The remainder of the paper is organized as follows. Section 2 recaps the anti-union legislative process in Wisconsin and Ohio and presents hypotheses. Section 3 describes the data and methodology used in the analysis. Section 4 discusses the results of the analysis. Finally, Section 5 concludes the paper.

\section{Pension cut back Legislation}

The financial crisis and the resulting economic recession of the late 2000 s caused the steepest decline in state tax receipts on record. As of the third quarter of 2010, state tax collections, adjusted for inflation, were 11 percent below pre-recession levels. However, the need for state funded services did not decline. As a result, even after making very deep spending cuts, states continued to face large budget gaps. Forty-four states and the District of Columbia were projecting budget shortfalls for fiscal year 2012, which began July 1, 2011. These deficits followed large shortfalls in fiscal years 2009 through 2011. The budget difficulties led at least 46 states to reduce services to their residents and over 30 states to raise taxes to at least some degree, in some cases quite significantly. ${ }^{7}$

As projected revenue remained depressed at low levels, many states looked to additional spending and service cuts as well as further increases in taxes. However, states recognized that spending cuts are problematic during an economic downturn because they reduce overall demand and can result in the downturn getting even deeper. Spending cuts result in, among other things, employee layoffs, cancellations of contracts with vendors, and cutting of benefit payments to individuals, all of which directly remove demand from the state's economy. Tax increases also remove demand from the economy by reducing the amount of money people have to spend. Thus, increasing spending cuts and taxes to reduce state budget shortfalls place a considerable

\footnotetext{
${ }^{7}$ States Continue to Feel Recession's Impact, Center on Budget and Policy Priorities, March 9, 2011
} 
number of jobs at risk.

As the recession dragged on, states, struggling to further cut spending and increase taxes to address budget deficits, also began to seriously consider reducing state employee benefits. Approximately 80 percent of state, county, and city budget deficits are the result of employee costs. ${ }^{8}$ Further, the Bureau of Labor Statistics at the U.S. Department of Labor estimates that, as of 2009, state and local government employees received benefits that were 69 percent higher than those in the private sector (this on top of wages that topped their private sector counterparts). ${ }^{9}$ Without reform, these disparities were projected to increase. For example, in the late 2000s, the lifetime employment costs of a government worker in the state of Ohio were 221 percent higher than that for a private sector employee. In 2011, Ohio had an $\$ 8$ billion budget gap. Data showed that realigning Ohio state worker compensation packages to match those of their private sector peers would save taxpayers over $\$ 2.1$ billion in 2011 and 2012 (or 28 percent of the $\$ 8$ billion deficit). ${ }^{10}$ Thus, as states looked for ways to reduce budget deficits (particularly ways that would not put jobs at risk), many states turned to pension reform. Since most state workers were unionized, states needed to reduce or remove collective bargaining rights of these state employees to accomplish the desired pension reform. By March 2011, fifteen states had proposed legislation which would remove some collective bargaining powers from unionized state workers and allow states to reduce their contributions to public employee pension and health care plans. Wisconsin and Ohio were the first two states to actually pass reform legislation (Wisconsin on March 11, 2011 and Ohio on March 31, 2011).

Public employees saw these changes in their collective bargaining rights as an assault on their rights as union workers. Thus, these pension reform bills became associated with anti-union

\footnotetext{
${ }^{8}$ Property Tax Woes Man More Local Budget Pain, Public Sector, Inc. March 14, 2012.

${ }^{9}$ U.S. Bureau of Labor Statistics, Employer Costs for Employee Compensation survey, December 2009

${ }^{10}$ The Buckeye Institute for Public Policy Solutions, press release, July 2010.
} 
movements intended to weaken the power of labor unions. In February 2011, a series of public employee protests began. A number of Wisconsin legislators and judges were sympathetic to the unions' arguments. These politicians and judges took actions to prevent passage and enactment of the Wisconsin reform bill: most notably was the walkout of 14 Wisconsin Senate Democrats who fled the state to deprive Republicans of the three-fifths majority needed to pass a reform bill. Further, while Wisconsin's reform bill was signed into law on March 11, 2011, just five days later the Dane County District Attorney filed a legal challenge to the bill, stating that Republican lawmakers violated Wisconsin's open meetings law (by not giving the proper public notice that the committee planned to meet) when they amended the plan. The challenge requested that a Dane County Circuit Court judge void the law and issue an emergency order blocking the secretary of state from publishing the law. One week later the judge temporarily blocked the law from taking effect. Then on March 31, the law was put on indefinite hold by the same judge until the case could be heard by the Wisconsin Supreme Court. Thus, at this point, the union bill would not go into effect. On May 27, 2011 the Dane County Judge issued a permanent injunction that effectively threw out the anti-union bill. Despite these actions to overturn the bill, on June 15, 2011 the Wisconsin Supreme Court rejected the ruling from the county court that invalidated the anti-union bill and two weeks later, on June 29, 2011, the antiunion bill officially took effect.

Ohio's anti-union bill moved quickly through the legislative process. On February 1, 2011, Bill 5 (the anti-union bill) was introduced in the Ohio Senate and the bill was signed into law on March 31, 2011. However, after this relatively swift passage opponents of the bill started the repeal process. And on November 8, 2011, the bill was overwhelmingly repealed: by a vote of $61 \%$ in favor of repeal to $39 \%$ against repeal. 
Despite union protests and legislative actions to prevent changes in collective bargaining rights and pension reform from enactment, the soaring levels of state employee benefits were seen as unsustainable cost drivers that threatened the financial solvency of many states. Thus, states continued their pursuit of pension reform. The reform in Wisconsin and Ohio requires state workers to contribute a larger share of their pension and health care costs. In Wisconsin, state workers would make a 5\% contribution to their pensions and increase their share of health insurance costs up to $12 \%$. Most state workers contributed nothing to their pensions and paid between $4 \%$ and $6 \%$ of their health insurance costs prior to passage of the reform bill. The reform was expected to save the state $\$ 1.5$ billion. The state had a budget deficit of $\$ 3.6$ billion at the time. In Ohio, the bill bans strikes by public workers and establishes penalties for those who participate in walkouts. Unionized workers can negotiate wages, hours, and certain work conditions but not health care, sick time, or pension benefits. The reform was expected to produce savings of $\$ 2.1$ billion dollars. The state had a budget deficit of $\$ 8$ billion at the time.

Given the expected costs savings, changes in union employees' bargaining rights and pension reform in Wisconsin and Ohio should result in a decrease in the strain on the states' budgets. Successful passage of this type of legislation arguably improves states' budget situations and thus, improves the general economic conditions in the states. Banks, in their role as lenders to municipalities, businesses, and consumers in the states, would directly feel the effects of changes in the economic condition of the states in which they operate.

For example, this legislation should increase the probability that states can make their promised payments on municipal securities issued by the state. This, in turn, should result in municipal securities issued by the states of Wisconsin and Ohio being less risky. Thus, through holding state-issued bonds, banks would directly feel the effects of changes in the economic 
condition of the states. Accordingly, events that signal an increased (decreased) probability of passage of pension reform (anti-union) legislation in Wisconsin and Ohio should result in positive (negative) value changes for banks that operate in these states and hold municipal securities issued by them. Further, as Wisconsin and Ohio went through the legislative process, other states in the process of, or considering, pension and union bargaining rights reform could take progress or protest in Wisconsin and Ohio as a sign of the likelihood of successful reform in their own states. Accordingly, we test the following hypotheses:

Hypothesis 1: Bank stock returns adjust positively (negatively) to news that conveys an increased (decreased) probability of Wisconsin's and Ohio's passage of anti-union legislation.

Hypothesis 2: Bank stock return adjustments to news of Wisconsin's and Ohio's anti-union legislation prospects reflect banks' business activity in an anti-union legislation state.

\section{Data and Methodology}

\subsection{Data}

The sample examined in this study includes all publicly traded banks head-quartered in the United States and operating during the first quarter of 2011. All accounting data used throughout the study are obtained from FFIEC Call Reports databases found on the Chicago Federal Reserve's Website. Data on banks are collected at the holding company level. That is, based on the highest holding company number of the bank, we collect and combine data for all banks with the same highest holding company number. Thus, we treat the bank holding companies as if they have only one bank, by combining their subsidiaries into one (consolidated) statement. Bank stock return data are collected from the Center for Research in Security Prices (CRSP) data tapes. Our analysis includes a total of 329 banks.

To test our hypotheses, we ideally would like to use banks that are headquartered in Wisconsin, Ohio, or any of the other 13 states that had introduced some type of anti-union 
legislation. A bank that is headquartered in one of the "anti-union legislation" states is more likely to be doing business in one of these states. However, we find that only 2 U.S. banks are headquartered in Wisconsin and only 14 banks are headquartered in Ohio. Next, we rationalize that banks headquartered in a particular state can do business in many states. For example, banks headquartered in Illinois are likely to be issuing assets, collecting deposits, and buying municipal securities issued by the state of Wisconsin. Thus, we next attempt to collect the dollar value of assets each U.S. bank has located in Wisconsin, Ohio, or any of the other 13 states that had introduced some type of anti-union legislation. However, the dollar value of assets (e.g., loans) issued by a bank in a particular state is also not available in Call Reports. Finally, rather than using assets to measure the extent to which a bank conducts business in a particular state, we examine the amount of deposits issued in Wisconsin, Ohio, or any of the other 13 states that had introduced some type of anti-union legislation to the total deposits of the bank. Data on deposit holdings of banks by state are listed in the FDIC's Summary of Deposits web site, http://www2.fdic.gov/sod. Thus, our measure of the extent to which a bank conducts business in Wisconsin, Ohio, or any of the other 13 states that had introduced some type of anti-union legislation is the amount of deposits held in the state to the total deposits of the bank. Any bank that has at least one percent of its deposits located in Wisconsin is classified as a "Wisconsin bank." Any bank that has at least one percent of its deposits located in Ohio, and is not already classified as a "Wisconsin" bank, is classified as an "Ohio bank." Finally, any bank that has at least one percent of its deposits located in any of the other 13 states that had introduced some type of anti-union legislation, and is not already classified as a "Wisconsin" or an "Ohio" bank, is classified as a "13 other anti-union states" banks. 
Having identified banks by state in which they operate, we would next like to use banks' holdings of municipal securities issued by Wisconsin, Ohio, or any of the other 13 states that had introduced some type of anti-union legislation. However, this level of detail regarding banks' municipal securities portfolios is not available in Call Reports or elsewhere to our knowledge. Thus, we collect total municipal securities held by each bank. It is likely that a bank that conducts business in one of the "anti-union legislation" states is more likely to be holding municipal securities issued by one of these states and that the greater the amount of business conducted in a state, the greater would be the holdings of municipal securities issued by the state. We contacted about a dozen banks in Wisconsin and Ohio to enquire about the composition of their municipal securities portfolios. They all indicated that they hold state/local debt instruments of their own state and no other state. They also stated that this is not a home state bias. Rather, they hold local municipal securities to develop relations with their own localities with the hope of getting lending and deposit taking business from the municipalities in return.

Data are obtained to measure the following bank characteristics: (a) dollar value of deposits located in Wisconsin, Ohio, or any of the other 13 states that had introduced some type of anti-union legislation, (b) total deposits, (c) municipal securities holdings, (d) book value of total assets, and (e) tier I capital ratios. Financial statement information is collected for year-end 2010. Table 1 lists the number of banks in the sample listed by the state in which the bank holds deposits. Table 2 lists descriptive statistics (mean, median, standard deviation, minimum, and maximum) for the 329 sample banks. As can be seen in Table 1, 8 of the sample banks have at least $1 \%$ of their deposits located in Wisconsin (these banks have an average of $52.08 \%$ of the their total deposits located in the 15 anti-union legislation states), an additional 26 banks have at least $1 \%$ of their deposits located in Ohio (and an average of $62.91 \%$ of the their total deposits 
located in the 15 anti-union legislation states), and 147 banks have at least $1 \%$ of their deposits located in any of the other 13 states that had introduced some type of anti-union legislation (and an average of $69.27 \%$ of their total deposits located in the anti-union legislation states).

From Table 2, we can see that the 8 banks with deposits located in Wisconsin have a mean value of assets of $\$ 97.1$ billion (median $=\$ 26.5$ billion), the 26 banks with deposits located in Ohio have a mean value of assets of $\$ 160.5$ billion (median $=\$ 5.4$ billion), and the 147 with deposits located in the other 13 anti-union legislation states have a mean value of assets of $\$ 70.2$ billion (median $=\$ 3.5$ billion). Banks with no deposits located in the 15 anti-union legislation states are much smaller: averaging $\$ 8.6$ billion (median $=\$ 2.2$ billion). While we compare results for larger banks that operate in anti-union states with smaller banks that have no deposits in anti-union states, we will see below that results are strongest for small banks. ${ }^{11}$ Thus, the implications for value changes attached to banks due to difference in size for the treated banks and the control banks should be minimized.

On average, all groups of banks are healthy, as measured by the tier I capital ratio: averaging $11.38 \%$ percent for the Wisconsin banks (ranging from $9.17 \%$ to $15.10 \%$ ), $11.89 \%$ for Ohio banks (ranging from $6.34 \%$ to $18.47 \%$ ), $12.57 \%$ for the other 13 anti-union state banks (ranging from $2.37 \%$ to $22.00 \%$ ), and $12.45 \%$ for all other publicly traded banks (ranging from $1.24 \%$ to $25.56 \%)$. Note that the vast majority of these capital ratio numbers are well above the minimum required tier I capital ratio needed for "adequately" capitalized banks (which is 4\%). The ratio of municipal securities to total assets averages 3.01\% for the Wisconsin banks (ranging from $0.45 \%$ to $7.55 \%$ ), $3.96 \%$ for Ohio banks (ranging from $0.00 \%$ to $17.22 \%$ ), $3.10 \%$ for banks in the other 13 anti-legislation states (ranging from $0.00 \%$ to $24.96 \%$ ), and $4.72 \%$ for all other

\footnotetext{
${ }^{11} \mathrm{We}$ also performed our analysis using a matched sample to compare against banks in anti-union states. Conclusions based on the matched sample are consistent with results presented in the paper and are available on request.
} 
publicly traded banks (ranging from $0.00 \%$ to $25.38 \%$ ). Likewise, the ratio of municipal securities to tier I capital averages $48.51 \%$ for the Wisconsin banks (ranging from $8.22 \%$ to $102.91 \%$ ), $51.02 \%$ of total assets for Ohio banks (ranging from $0.04 \%$ to $169.29 \%$ ), $40.09 \%$ for banks in the other 13 anti-legislation states (ranging from $0.00 \%$ to $249.64 \%$ ), and $58.51 \%$ for all other publicly traded banks (ranging from $0.00 \%$ to $308.07 \%$ ). Note that banks without deposits in the 15 anti-union legislation states actually hold more municipal securities than banks with deposits in these states. While we cannot verify the state in which these municipal securities are issued, given that these banks have no deposits in any of the 15 anti-union states, they are reasonably least likely to be holding municipals issued in these states. That said, we test to see how the values of these banks are affected by anti-union legislation in the 15 anti-union legislation states.

The tests performed on the sample require us to identify dates on which important new information about the abolition of public union bargaining rights became publicly available. News items pertaining to the anti-union bills are compiled by examining articles retrieved from a Google search using the keywords Wisconsin union (anti-union) bill, Ohio union (anti-union) bill, states with anti-union bills, and anti-union legislation. As of March 2011, 15 states had introduced some type of anti-union legislation. However, it is the legislation in Wisconsin and Ohio that received the earliest and most widespread attention in the press. Thus, we focus our analysis on announcements associated with passage of legislation in Wisconsin and Ohio. While our search produces several events associated with the passage of Wisconsin and Ohio anti-union rights bills, we require that there be at least 5 items listed about an event to be included. This leaves us with 20 events relating to major announcements. Table 3 lists the event dates and a short description of each (events pertaining to the Ohio anti-union legislation are italicized, while 
events pertaining to Wisconsin anti-union legislation are not). For each event, the table also lists our anticipated announcement period stock price reaction for the sample banks.

Wisconsin's anti-union bill took a tumultuous and highly publicized path to passage. On December 7, 2010 (event 1 listed in Table 3) Governor-elect Walker first released details of a proposal to save millions of dollars by having state employee union members pay more into pension funds and pay more for health insurance. To get such concessions Governor-elect Walker raised the possibility of changing state law to decertify the unions. On February 2, 2011 (event 3), Governor Walker affirmed in his State of the State address that state of Wisconsin employees needed to contribute to their pension costs and pay more for health insurance to help balance the Wisconsin state budget. These comments quickly became legislation as a bill eliminating most collective bargaining rights from nearly all Wisconsin public employees passed the legislature's budget writing committee on February 17 (event 4 in Table 3). After this vote, Democratic lawmakers left the state in an attempt to stop a vote on the bill. Despite this, on February 24 (event 5) the Assembly reached an agreement on the contents of the bill, on March 9 (event 7) the Assembly passed the bill (despite the absence of 14 Democratic senators), and on March 11 (event 8) Governor Walker signed the bill into law. This was not the end, however, as just five days later (event 9) the Dane County District Attorney filed a legal challenge to the bill, stating that Republican lawmakers violated Wisconsin's open meetings law (by not giving the proper public notice that the committee planned to meet) when they amended the plan. The challenge requested that a judge void the law and issue an emergency order blocking the secretary of state from publishing the law. On March 18 (event 10), the judge temporarily blocked the law from taking effect. In an unexpected and confusing move, on March 25 (event 11 in Table 3) the Legislative Reference Bureau published the law (the last step before the law 
goes into effect), despite the court order blocking its publication while challenges to the law were being considered. However, on March 31 (event 14), the law was put on indefinite hold by the same Dane County Circuit Court judge until the case could be heard by the Wisconsin Supreme Court. Thus, at this point, the union bill would not go into effect. Further, the Supreme Court had not indicated whether it would even take the case. While the Wisconsin Supreme Court deliberated, on May 27, 2011 Dane County Judge MaryAnn Sumi issued a permanent injunction that effectively threw out the anti-union bill (event 16). Judge Sumi concluded that the Republicans passed the bill by violating the state's strong "open meeting" law that requires 24 hours' notice of official meetings, and that the law was thus invalid. This decision was reversed on June 15, 2011 (event 17), when the Wisconsin Supreme Court rejected the ruling from the county court that invalidated the anti-union bill. The unusually quick decision was decided by a vote of 4 to 3. Two weeks later, on June 29, 2011, the anti-union bill took effect (event 18).

Ohio's anti-union bill was passed in a more typically smooth manner than was Wisconsin's bill. On February 1, 2011, Bill 5 (the anti-union bill) was introduced in the Ohio Senate (event 2 in Table 3). This was followed by Senate approval (on March 2 (event 6)), approval by a House panel (on March 29 (event 12)), approval by the full House and Senate (on March 30 (event 13)), and the bill was signed into law on March 31, 2011 (event 14). After this relatively swift passage, however, opponents of the bill started the repeal process. On April 15, the Ohio Attorney General certified summary language for a referendum seeking repeal of Senate Bill 5 (event 15). This language needed to be certified in order for opponents of the bill to start collecting 231,150 signatures (within 90 days of the passage of the bill) needed to get it on the November ballot. On June 29 (event 18) opponents marched to the Secretary of State's office to hand over the petitions with 1,298,301 signatures and on July 21 the Ohio Secretary of State 
announced that sufficient signatures had been certified to put a repeal of Bill 5 on the November ballot as a veto referendum (event 19). On November 8, 2011, the bill was overwhelmingly repealed: by a vote of $61 \%$ in favor of repeal to $39 \%$ against repeal (event 20).

\subsection{Methodology}

To measure the stock market effect of announcements associated with anti-union legislation, we first analyze the cumulative effect of all major announcements on bank stock returns. We construct cumulative abnormal returns for each event from a Fama-French three factor model (Fama and French 1993). Since not all public banks trade regularly, we add additional lead and lag market excess return factors to control for nonsynchronous trading effects (Dimson 1979). In particular, we estimate the following model over the last half of $2010 .^{12}$

$$
r_{i, t}-r_{f, t}=\beta_{i, 1} * S M B_{t}+\beta_{i, 2} * H M L_{t}+\sum_{n=t-1}^{t+1} \beta_{i, 3+n-(t-1)} *\left(r_{m, n}-r_{f, n}\right)+\varepsilon_{i, t},
$$

where $i$ and $t$ index banks and events respectively, and where SMB equals the spread in returns

for small minus big market capitalization firms, HML equals the spread in returns for high minus low book-to-market ratio firms, and $r_{m, n}-r_{f, n}$ is the value-weighted excess market return relative to the one-month Treasury bill. We require each regression to cover at least 25 observations (or 20 degrees of freedom). To test hypothesis 1, we use the parameter estimates of Equation 1 to estimate cumulative abnormal returns (CARs) by compounding residual estimates over the threeday window centered around each announcement: ${ }^{13}$

$$
C A R_{i, t}=\prod_{\tau=t-1}^{t+1}\left(1+\hat{\varepsilon}_{i, \tau}\right)-1
$$

\footnotetext{
12 We use the latter half of 2010 as our estimation pre-period to avoid volatility related to the banking sector crisis which curtailed during the first half of 2010, however results are robust to estimating Eq. 1 using all data from 2010.

${ }^{13}$ Because we have three events over the period March 29-31, we also examine a five-day window centered around March 30, 2011.
} 
where $\quad \hat{\varepsilon}_{i, t}=r_{i, t}-\left(\hat{\beta}_{i, 1} * S M B_{t}+\hat{\beta}_{i, 2} * H M L_{t}+\sum_{n=t-1}^{t+1} \hat{\beta}_{i, 3+n-(t-1)} *\left(r_{m, n}-r_{f, n}\right)\right)$, which makes use of the parameter estimates produced by Equation 1, denoted $\hat{\beta}$.

To test hypothesis 2 , we run cross-sectional tests to gauge each event's influence in the underlying data. That is, for each event $t$ and each bank $i$ we run various forms of the following regression:

$C A R_{i}=\alpha+\delta_{1} \ln \left(\right.$ assets $\left._{i}\right)+\delta_{2} \ln \left(1+{\left.\text { tier I } \text { capital }_{i}\right)}+\delta_{3}\right.$ Municipals to tier I capital $_{i}+\delta_{4}$ Deposits held in Wisconsin to total deposits $\mathrm{i}_{\mathrm{i}}+\delta_{5}$ Deposits held in Ohio to total deposits ${ }_{i}+\delta_{6}$ Deposits held in any of the other 13 anti-union states to total deposits $s_{i}+\varepsilon_{i}$.

Standard errors are clustered by bank headquarter state since state-specific banking laws may create correlations within announcement returns. The $\delta_{1}, \delta_{2}$, and $\delta_{3}$ factors are lagged by one year.

Equation 3 tests hypotheses 1 and 2 across banks within each event. However segmenting the data this way reduces our degrees of freedom, and, importantly, ignores potentially correlated errors due to event-level clustering. We therefore test our hypotheses more formally by pooling the data and additionally clustering by event. Since different events associate with varying signed predictions, we sign our test proxy according to the hypothesized sign of each event within the sample (shown in Table 3). The model is:

$C A R_{i, t}=\alpha+\delta_{1} \ln \left(\right.$ assets $\left._{i, t}\right)+\delta_{2} \ln \left(1+\right.$ tier I capital ratio $\left.{ }_{i, t}\right)+\delta_{3}$ Municipals to tier I capital $_{i, t}+$

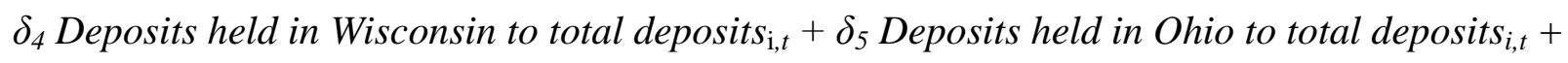
$\delta_{6}$ Deposits held in any of the other 13 anti-union states to total deposits $s_{i, t}+\varepsilon_{i, t}$,

where $i$ and $t$ index banks and events, $\delta_{1}, \delta_{2}$, and $\delta_{3}$ factors are again lagged by one year.

\section{Results}

\subsection{Announcement Period Abnormal Returns by Event}


Table 4 reports portfolio three-day cumulative abnormal returns estimated from equation (2) around each of the 20 events for 329 banks in our sample. Columns 1 and 2 list the events and event dates, respectively. Columns 3 and 4 report the portfolio abnormal returns and the tstatistics for Wisconsin banks; Columns 5 and 6 report the portfolio abnormal returns and the tstatistics for Ohio banks; Columns 7 and 8 report the portfolio abnormal returns and the tstatistics for banks in the 13 other anti-union states; and Columns 9 and 10 report the portfolio abnormal returns and the t-statistics for all other banks.

From the results in Table 4, we find that four of the 20 events produce significant CARs with the expected sign (event 4 - bill clears committee/Democratic lawmakers leave state is negative and significant for Ohio banks and banks in the other 13 anti-union states, event $10-$ Wisconsin state judge puts law on hold is negative and significant for Ohio banks, banks in the other 13 anti-union states, and banks in all other states, event 18 - Wisconsin anti-union law goes into effect/Ohio opponents submit signatures needed to get repeal of bill on November ballot is negative and significant for Ohio banks, and event 20 - Ohio voters repeal new law that would limit bargaining rights is negative and significant for banks in the 13 other anti-union states).

With the lack of significance in these CARs we cannot confirm of hypothesis 1 that bank stock returns react to announcements regarding the probability of passage of Wisconsin's and Ohio's anti-union legislation. However, the CARs reported in Table 4 do not condition on the extent to which a bank does business in a state (i.e., the state deposit ratio). For example, from Table 2 we know that the banks that operate in Wisconsin have as little as $1.59 \%$ of their deposits located in Wisconsin and as much as $100 \%$. We would not expect banks that conduct a small percentage of their business in Wisconsin (i.e., $1.59 \%$ of total deposits) to react as strongly to anti-union legislation events as those doing a large amount of business in Wisconsin (i.e., 
$100 \%)$. Thus, we move to regression analysis to examine whether announcements associated with the passage of Wisconsin and Ohio's anti-union legislation are significantly related to the extent to which a bank conducts business in an anti-union legislation state.

\subsection{Pooled Regression Results}

Table 5 reports results of the pooled cross-section model. Regression 1 isolates the impact of anti-union legislation on Wisconsin banks; Regression 2 isolates the impact of anti-union legislation on Ohio banks; Regression 3 reports the combined impact of anti-union legislation on Wisconsin and Ohio banks; and Regression 4 reports the impact of anti-union legislation on the other 13 anti-union state banks.

Pooling across all 20 events and all sample banks, Table 5 reports that anti-union legislation delivers statistically significant stock price reactions from banks doing business in Wisconsin and Ohio in accordance with the signed predictions of Table 3, and jointly consistent with hypotheses 1 and 2 . Regressions 1,2, and 3 report that the greater the extent to which a bank does business in either of these states the greater the bank's stock price reaction to the sequence of events associated with passage of anti-union laws (coefficient on deposits held in Wisconsin to total deposits in regression $1=0.008$, coefficient on deposits held in Ohio to total deposits in regression $2=0.003$, and coefficient on deposits held in either Wisconsin or Ohio to total deposits in regression $3=0.004$, all are significant at $1 \%$ ). Thus, the increased probability of anti-union legislation being passed in Wisconsin and Ohio is positive news for banks doing business in these states. In contrast, the increased probability of anti-union legislation being passed in Wisconsin and Ohio does not impact stock prices for banks doing business in the 13 other states considering anti-union legislation (regression 4 coefficient on deposits held in 13 
states to total deposits $=-0.001)$.

In all regressions, the greater the holdings of municipal securities to tier I capital, the more positive is the stock price reaction (coefficient $=0.003$ in all regressions, significant at $10 \%$ ) (thus, confirming hypothesis 2). Finally, smaller banks and banks with more tier I capital experience stronger, positive stock price reactions over all events (in all regressions, coefficient on $\ln ($ assets $)=-0.012$ and coefficient on $\ln (1+$ tier $\mathrm{I})=0.014$, all significant at $5 \%)$.

\subsection{Regression Results by Event}

After seeing results for the pooled sample, a natural question arises: Which events drive these results? To identify major events, we examine regression results using one event at a time. We find that eight events produce a significant relationship between abnormal announcement period returns and the individual characteristics of the sample banks with the expected sign (consistent with hypotheses 1 and 2). Table 6 reports regressions for these eight events; the Appendix to the paper reports regressions for the other twelve events that do not produce significant results. For each event date, three regressions respectively report: (1) the impact of the extent to which a bank conducts business in Wisconsin (measured as deposits held in Wisconsin to total deposits); (2) the impact of the extent to which a bank conducts business in Ohio; and (3) the impact of the extent to which a bank conducts business in any of the 13 other states in which anti-union legislation was under consideration.

On February 1, 2011 Bill 5 was introduced in the Ohio Senate; the next day, February 2, 2011, Wisconsin Governor Walker targeted state worker benefits in a speech. Both of these events signal an increased probability of the passage of anti-union legislation. Regressions 1 and 2, for February 1, 2011, report that the greater the extent to which a bank does business in either 
of these states the more positive is the bank's stock price reaction to the news (coefficient on deposits held in Wisconsin to total deposits in regression $1=0.022$ and coefficient on deposits held in Ohio to total deposits in regression $2=0.022$ for Ohio banks, both significant at $1 \%$ ) Consistent with hypotheses 1 and 2, the increased probability of anti-union legislation being passed in Wisconsin and Ohio appears to be positive news for banks doing business in these states. Surprisingly, the greater the extent to which a bank does business in the 13 other antiunion states, the more negative is the bank's stock price reaction to the news (regression 3 coefficient on deposits held in 13 states to total deposits $=-0.014$, significant at $10 \%)$. Thus, the increased probability of anti-union legislation being passed in Wisconsin and Ohio does not elicit positive news for banks in the other anti-union states.

Further, in regressions 1 and 2 the greater the holdings of municipal securities to tier I capital, the more positive is the stock price reaction (coefficient $=0.007$ in both regressions, significant at 10\%). Finally, we find that smaller banks and banks with more tier I capital experience stronger, positive stock price reactions to the February 1, 2011 event (for example, coefficient on $\ln ($ assets $)=-0.050$ and coefficient on $\ln (1+$ tier $I)=0.054$ in regression 1 , both are significant at $1 \%$ ). These results are generally consistent throughout all events in Table 6.

On February 17, 2011 the Wisconsin bill cleared the legislature's budget writing committee. After this vote, Democratic lawmakers left the state in an attempt to stop a vote on the bill. Regression 1 reports that the greater the extent to which a bank does business in Wisconsin the greater the bank's stock price reacts positively to the news (coefficient on deposits held in Wisconsin to total deposits in regression $1=0.026$, significant at $1 \%$ ). Thus, even though the walkout by lawmakers was intended to stop a subsequent vote on the bill, the clearing of the bill by the budget writing committee appears to be positive news for banks in the state. The event 
is insignificant for banks doing business in other states.

On March 2, 2011 the Ohio Senate approved the anti-union bill. Regressions 1 and 2 report that the greater the extent to which a bank does business in either Wisconsin or Ohio the greater the bank's stock price reacts positively to the news (coefficient on deposits held in Wisconsin to total deposits in regression $1=0.026$ (significant at $5 \%$ ) and coefficient on deposits held in Ohio to total deposits in regression $2=0.004$ for Ohio banks (significant at 10\%)). Thus, the increased probability of anti-union legislation being passed in Ohio appears to be positive news for banks in both Wisconsin and Ohio. The event is insignificant for banks doing business in the 13 other antiunion states (regression 3 coefficient on deposits held in 13 states to total deposits $=-0.005$ ).

On March 9, 2011 the Wisconsin assembly passed the anti-union bill despite the absence of the 14 Democratic senators. This event appears to have a positive but statistically weak impact on banks doing business in Wisconsin. Further, the greater the extent to which a bank does business in Ohio the greater the bank's stock price reacts positively to the news (coefficient on deposits held in Ohio to total deposits in regression $2=0.020$, significant at $1 \%$ ). Thus, this event (signaling positive news about the passage of anti-union legislation in Wisconsin) appears to be positive news for banks in Ohio (also going through the process of anti-union legislation).

On March 25, 2011 the Legislative Reference Bureau published the Wisconsin anti-union law (the last step before the law goes into effect), despite the court order blocking its publication while challenges to the law were being considered. While bank stock returns for this event are not related to the extent to which banks do business in Wisconsin, we find that the greater the extent to which a bank does business in Ohio the greater the bank's stock price reacts positively to the news (coefficient on deposits held in Ohio to total deposits in regression $2=0.017$, significant at 1\%). Thus, this event (that signals positive news about the passage of anti-union 
legislation in Wisconsin) also appears to be positive news for banks in Ohio.

On March 29, 2011 Ohio's anti-union bill was approved by a House panel, on March 30 the bill was approval by the full House and Senate in Ohio, and on March 31 the bill was signed into law. The three consecutive events signal an increased probability of the passage of antiunion legislation. However, on March 31, the Wisconsin law was put on indefinite hold by the Dane County Circuit Court judge until the case could be heard by the Wisconsin Supreme Court. Thus, at this point, the union bill would not go into effect. Further, the Supreme Court had not indicated whether it would even take the case. This event signals a decreased probability of the passage of Wisconsin's anti-union legislation. Because we have three similar Ohio-based events over the period March 29-31, we examine both a three-day and a five-day window centered around March 30, 2011. Using the three-day event window, we find that only banks doing business in Wisconsin are impacted by the events. Specifically, the greater the extent to which a bank does business in Wisconsin the greater the bank's stock price reacts negatively to the news (coefficient on deposits held in Wisconsin to total deposits in regression $1=-0.010$, significant at $1 \%)$. Thus, it appears that over the three-day window, Wisconsin banks react to the negative news (the law was put on indefinite hold). However, using the five-day event window, we find that only banks doing business in Ohio are impacted by the events. Specifically, the greater the extent to which a bank does business in Ohio the greater the bank's stock price reacts positively to the news (coefficient on deposits held in Ohio to total deposits in regression $2=0.013$, significant at $1 \%$ ). Thus, it appears that over the five-day window, Ohio banks react to the positive news (the bill was approval by a House panel and then was approval by the full House and Senate in Ohio).

On May 27, 2011 the Dane County Judge issued a permanent injunction that effectively 
threw out Wisconsin's anti-union bill, concluding that the Republicans passed the bill by violating the state's strong "open meeting" law, and that the law was thus invalid. Regression 1 reports that the greater the extent to which a bank operates in Wisconsin the more negatively the bank's stock price reacts to the news (coefficient on deposits held in Wisconsin to total deposits in regression 1 $=-0.011$, significant at $10 \%$ ). No other states' banks react to this event, consistent with the statespecific nature of this “open meeting” injunction eliciting a state-specific bank response.

Finally, on June 29, 2011 anti-union legislation became reality as Wisconsin's anti-union law went into effect. Also on this day, Ohio opponents submitted signatures needed to get a repeal of Bill 5 on the November ballot. Regression 1 reports that the greater the extent to which a bank does business in Wisconsin, the greater the bank's stock price reacts positively to the news (coefficient on deposits held in Wisconsin to total deposits in regression $1=0.118$, significant at $1 \%$ ). Thus, the implementation of anti-union legislation in Wisconsin appears to be positive news for banks in these states. Further, the greater the extent to which a bank does business in Ohio, the more negative is the bank's stock price reaction to the news (regression 2 coefficient on deposits held in Ohio to total deposits $=-0.012$, significant at $5 \%$ ). Thus, news that Ohio's anti-union legislation would be up for a vote on the November ballot appears to be bad news for banks operating in Ohio. Despite the enactment of anti-union legislation and the resulting easing of the strain on Wisconsin's state budget, the increased possibility of repeal of the Ohio anti-union bill appears to dominate the relation between banks' holdings municipal securities and stock price reactions to this event.

Results in Table 6 are consistent with results from Table 5. That is, we find that several events surrounding the passage of anti-union legislation impact bank values. Events signaling an increased (decreased) probability of passage of legislation have a positive (negative) impact on 
bank values. Banks conducting business in Wisconsin and Ohio, the first two states to pass antiunion legislation, experience the largest reactions to the events. Further, we find evidence that larger the holdings of municipal securities, result in larger reactions to particular events.

Table 7 reports pooled data regression results for the 8 events for which the individual event regressions reported in Table 6 identify significant relations. Similar to the results in Table 5, the resulting bank-event level panel admits multiple observations per bank. Results using all banks and the 8 events for which the individual event regressions reported in Table 6 identify significant relations are similar to those including all events (in Table 5). That is, anti-union legislation has a positive stock price reaction for banks doing business in Wisconsin and Ohio. Regressions 1,2, and 3 again report that the greater the extent to which a bank does business in either of these states the greater the bank's stock price reaction to the sequence of events associated with passage of anti-union laws (coefficient on deposits held in Wisconsin to total deposits in regression $1=0.026$, coefficient on deposits held in Ohio to total deposits in regression $2=0.008$, and coefficient on deposits held in either Wisconsin or Ohio to total deposits in regression $3=0.010$ ). However, the significance levels are higher in all cases. In addition, the increased probability of anti-union legislation being passed in Wisconsin and Ohio has a negative impact on stock prices for banks doing business in the 13 other states considering anti-union legislation (regression 4 coefficient on deposits in 13 states to total deposits $=-0.006$, significant at 10\%). Further, smaller banks and banks with more tier I capital experience stronger, positive stock price reactions over all events. However, holdings of municipal securities to tier I capital are no longer significant.

\subsection{Robustness Tests}

\section{4.a. Results for Industrial Firms}


A general question is why this paper looks at banks, as opposed to other firms doing business in Wisconsin and Ohio, or perhaps businesses using unionized workers (or other holders of muni bonds). The intuitive response to this question is that banks conduct business with many groups in a state (businesses, individuals, and municipalities). Thus, banks that conduct business in an anti-union state would feel the effects of anti-union legislation through multiple fronts. Accordingly, banks should exhibit a stronger overall reaction to anti-union legislation than industrial firms in these states. To examine the effect of anti-union legislation on banks versus other firms in anti-union states, we collect stock returns of all industrial firms over the period of analysis. We also collect information on the state in which each industrial firm is headquartered and (as a control variable) each firm's leverage ratio (defined as total debt to total assets). Using regressions similar to equations 1-3 (but applied to industrial firms), we test the impact of industrial firms' state headquarter indicators on abnormal returns.

The results of these regressions are reported in Table 8 . The setup for Table 8 is similar to that of Tables 5 and 7. Regression 1 isolates the impact of anti-union legislation on industrial firms headquartered in Wisconsin; Regression 2 isolates the impact of anti-union legislation on firms headquartered in Ohio; Regression 3 reports the combined impact of anti-union legislation on firms headquartered in either Wisconsin or Ohio. In all regressions, we see no evidence that the increased probability of anti-union legislation being passed in Wisconsin and Ohio impacts stock prices of industrial firms headquartered in these two states.

\section{4.b. Announcement Effects and Municipal Bond Spreads}

If anti-union legislation affects bank valuations directly through changing default risk exposures in banks' municipal bond portfolios (as a result of shifts in investor expectations of states' 
budget solvency), then we would also expect municipal spreads on debt issued by Wisconsin or Ohio to decrease more (less) on average for event days signaling an increased (decreased) probability of passage of legislation relative to municipal spread changes on non-event days, and relative to municipal spread changes on debt issued by other states on average. To test this, we collect daily historical municipal bond yields from Thomson Reuters Municipal Market Data and form spreads on states' AAA rated 10-year general obligation municipal bond rates over 10-year Treasury yields from 2007 through 2013. We then examine abnormal municipal spread changes for debt issued by Wisconsin and Ohio on event days relative to spread changes on non-event days and to spread changes on debt issued by other control states. ${ }^{14}$

Specifically, we model the daily variation in spreads, $\Delta \operatorname{Spread}_{i, t}$, using 1-day lead minus 1-day lagged spreads and AAA 10-year general obligation municipal bond rates benchmarked against 10 -year Treasury rates, as: $:^{15}$

$\Delta$ Spread $_{i, t}=\alpha+\beta_{1}$ EventIndicator $_{t}+\beta_{2}$ StateIndicator $_{i}+\beta_{3}$ EventIndicator $_{t} *$ StateIndicator $_{i}+e_{i, t}$

EventIndicator $r_{t}$ equals 1 when spread changes are centered around event days and 0 otherwise.

StateIndicator ${ }_{i}$ equals 1 when spread changes come from debt issued by Wisconsin or Ohio, and 0 otherwise. In the panel underlying equation 4 , we pool events by multiplying a value of -1 to the dependent variable when observations correspond to the negative events in Table $3 .{ }^{16}$ In equation $4, \alpha$ reports average spread changes in control states on non-event days, $\beta_{1}$ reports average spread changes in control states on event days, $\beta_{2}$ reports average spread changes in Wisconsin and/or Ohio (depending on the specification) on non-event day, and $\beta_{3}$ reports average abnormal spread changes in Wisconsin and/or Ohio on event days, incremental to the

\footnotetext{
${ }^{14}$ Preferential tax treatment of municipal bonds causes spreads to Treasury yields to sometimes be negative. However, examining daily changes in spreads differences out the tax effect.

${ }^{15}$ Since spread change volatility varies substantially across states, we winsorize spread changes within each state at $5 \%$ to prevent oversampling state's in which spread changes are generally more volatile.

${ }^{16}$ Events that are ambiguous (events 4 and 18 ) are left alone.
} 
spread changes measured by $\alpha, \beta_{1}$, and $\beta_{2}$.

Table 9 presents the regression results. Column 1 in panel A of Table 9 shows that daily spreads across control states on non-event days increase by 0.0021 percent on average during the 2010-2011 sample period, and the average increase is even greater, by 0.0038 percent, on event days. Average daily municipal spread changes on debt issued by Wisconsin are lower by 0.0005 percent over non-event days. However, over event days, municipal spreads on debt issued by Wisconsin decline by 0.0074 percent. All values are significant at $1 \%$. In column 2 , we see the average decline in municipal spreads on debt issued by Ohio on event days is much smaller, although still significant, 0.001 percent. Column 3 shows an overall combined and significant decline of 0.0043 percent in abnormal spread changes on Wisconsin and Ohio municipal debt on event days. Column 4 runs Wisconsin and Ohio effects together. This alleviates concern that estimated effects for Wisconsin and Ohio in columns 1 and 2 are due to spillover announcement effects from Ohio and Wisconsin in columns 2 and 1, respectively. The interaction estimates of column 4 are indeed very close to their counterparts in columns 1 and 2. Panel B shows broadly similar patterns with respect to the 8 primary event days. Note that column 1 of panel B delivers an event indicator estimate which decreases to -0.008 , down from 0.0038 in panel A. This swing indicates the relatively important influence the 8 primary events had on lowering municipal spreads across all states on average.

\section{4.c. Bank Lending Effects}

As a last test, we consider the long term impact of anti-union legislation resolutions in Wisconsin and Ohio on bank lending. The successful upholding of legislation restricting union bargaining rights in Wisconsin plausibly lowered the state's municipal debt default probabilities, thereby 
increasing asset values and freeing up lending capital of "Wisconsin banks." In Ohio, legislation restricting union bargaining rights was ultimately overturned. With an overall increase in default probability over the span of the debate, "Ohio bank" asset values tied to municipal bond holdings would decline, potentially tightening the credit supply of those banks overall.

To test this, we model the cross-section of changes in total bank loans as a function of banks' presence in Wisconsin and/or Ohio as follows:

$$
\Delta \text { TotalLoans }_{i}=\alpha+\beta_{1} \text { StateIndicator }_{i}+e_{i} .
$$

StateIndicator $_{i}$ equals 1 for Wisconsin or Ohio banks (depending on the specification), and zero otherwise. Because of their size-related abilities to operate in many states, large banks are not likely to be as sensitive to any particular state's solvency issues. ${ }^{17}$ To limit the effects of very large banks, we exclude observations in the top $1 \%$ for changes in total loans.

Table 10 presents the results. Panel A examines changes in total loans from 2008 through 2011, while panel B examines changes for a longer period after the anti-union legislation process is finalized, from 2008 through 2012. In both panels, Column 1 highlights the impact of the extent to which a bank conducts business in Wisconsin (the StateIndicator equals one for any bank that has at least one percent of its deposits located in Wisconsin and zero otherwise). Column 2 highlights the impact of the extent to which a bank conducts business in Ohio (the StateIndicator equals one for any bank that has at least one percent of its deposits in Ohio, and is not already classified as a "Wisconsin" bank and zero otherwise). Column 3 runs Wisconsin and Ohio effects together. Column 4 reports the combined impact of Wisconsin and Ohio banks.

The intercept coefficient in column 1 suggests that bank loan portfolios (including Ohio banks) on average remained flat from 2008 to 2011, decreasing slightly by $\$ 72$ million

\footnotetext{
${ }^{17}$ The results from equation 5 (discussed below) are robust to the inclusion of $\ln ($ assets), $\ln ($ tier 1 capital), and municipal holdings to tier I capital ratio as controls.
} 
(statistically indistinguishable from zero). Summing the intercept and the WI state indicator coefficient indicates Wisconsin bank loan portfolios increased significantly by an economically large $\$ 3.4$ billion overall (t-statistic $=2.390$, significant at $1 \%$ ). Thus, the WI indicator significantly differs from the intercept. The R-square statistic shows the WI indicator explains about $1.89 \%$ of the variation in total loan changes across the set of all publicly traded banks, which suggests a somewhat large overall explanatory power for an indicator variable covering only 1 state, especially given that WI contains relatively few banks (8).

In column 2, using an $\mathrm{OH}$ indicator, the intercept is still small but now slightly positive. This likely occurs because the control group now contains the Wisconsin banks, but not the Ohio banks. The negative $\mathrm{OH}$ indicator coefficient indicates that Ohio banks saw a large decline in total loans relative to the set of publicly traded banks (a statistically significant decrease of $\$ 2.15$ billion in total lending for Ohio banks relative to average changes in total lending across other banks, $\$ 2.35 \mathrm{~b}-\$ 0.2 \mathrm{~b})$. Thus, the ultimate upholding of union bargaining rights in budget constrained Ohio is associated with decreased lending activity across Ohio-based banks relative to banks in general. Column 3 runs both the WI and the $\mathrm{OH}$ banks indicators separately (removing both sets of banks from the control group) and shows the results from columns 1 and 2 are largely unchanged.

To help alleviate concerns over relying on a smaller numbers of banks in this set of tests (the 8 Wisconsin and 23 Ohio banks in our sample), column 4 of Table 10 pools the Wisconsin and Ohio banks, giving us a test group consisting of 31 observations. For this specification, we pool the data by creating an indicator equal to 1 for Wisconsin banks, -1 for Ohio banks (since anti-union legislation in Ohio was ultimately overturned), and zero otherwise. By pooling cases where union bargaining rights were upheld (Ohio) or reduced (Wisconsin), the indicator coefficient shows the overall average impact of anti-union legislation on bank lending regardless 
of the ultimate outcome. The combined indicator coefficient in column 4 indicates that antiunion legislation is associated with additional average absolute lending changes of about \$2.56 billion across Wisconsin and Ohio banks from 2008-2011.

In panel B of Table 10, which estimates the same specification using data from 20082012, column 1 shows a substantial further increase in the WI indicator point estimate (along with no material intercept change). This suggests that lending continued to increase into 2012 for Wisconsin banks. On the other hand, the point estimate on the Ohio bank indicator in column 2 of panel B is close in value to the column 2 indicator in panel A. This suggests the decrease in lending activity for Ohio banks in 2011, relative to 2008, persisted at least through 2012.

\section{Conclusions}

This study provides an empirical analysis of the impact of Wisconsin and Ohio anti-union legislation on values of banks operating in Wisconsin and Ohio, banks in other states in which anti-union measures were being considered as Wisconsin and Ohio went through its legislative process, and all other publicly traded U.S. banks. Successful passage of this type of legislation arguably improves states' budget situations. We find that banks doing business in Wisconsin and Ohio experience positive (negative) stock price reactions to announcements that indicate an increased (a decreased) probability of anti-union legislation. The stock price reactions are positively related to the extent to which banks operate in Wisconsin and Ohio banks and to the percentage of municipal securities held in the portfolios of banks. Stock price reactions are rarely evident for banks in the other 13 states that were considering anti-union legislation during the period of analysis. Robustness tests indicate that Wisconsin and Ohio municipal bond spreads decreased (increased) significantly in reaction to announcements that indicate an increased (a 
decreased) probability of anti-union legislation. Finally, we find that total lending by banks operating in Wisconsin increased over and after the period in which anti-union legislation was enacted, while total lending by banks operating in Ohio decreased over and after the period in which anti-union legislation was enacted and, eventually, overturned. 


\section{Table 1}

\section{Number of publicly traded banks by state}

This table lists publicly traded banks in existence at year-end 2010 by state in which the bank holds deposits. Data are obtained from FFIEC Call Reports databases found on the Chicago Federal Reserve's Website and the FDIC Summary of Deposits. To get the percent of deposits located in Wisconsin, Ohio, and 13 other anti-union legislation states we include data for only those banks in a state that have at least $1 \%$ of their deposits located in one of the anti-union states. Any bank that has at least one percent of its deposits located in Wisconsin is classified as a "Wisconsin bank." Any bank that has at least one percent of its deposits located in Ohio, and is not already classified as a "Wisconsin" bank, is classified as an "Ohio bank." Any bank that has at least one percent of its deposits located in any of the other 13 states that had introduced some type of anti-union legislation, and is not already classified as a "Wisconsin" or an "Ohio" bank, is classified as a "13 other anti-union states" banks. Non-anti-union state banks include banks with no more than $1 \%$ of their deposits in any of the 15 anti-union states.

\begin{tabular}{lcc}
\hline State & $\begin{array}{c}\text { Number of publicly } \\
\text { traded banks }\end{array}$ & $\begin{array}{c}\text { Average percent of deposits } \\
\text { located in the 15 anti- } \\
\text { union legislation states }\end{array}$ \\
Wisconsin & 8 & $52.08 \%$ \\
Ohio & 26 & 62.91 \\
13 other anti-union states & 147 & 69.27 \\
Non-anti-union states & 148 & 0.01 \\
\hline
\end{tabular}


Table 2

Descriptive statistics for 329 banks at year-end 2010

This table presents descriptive statistics for 329 publicly traded banks as of year-end 2010. Data are obtained from FFIEC Call Reports databases found on the Chicago Federal Reserve's web-site and the Federal Deposit Insurance Website Summary of Deposits. Any bank that has at least one percent of its deposits located in Wisconsin is classified as a "Wisconsin bank." Any bank that has at least one percent of its deposits located in Ohio, and is not already classified as a "Wisconsin" bank, is classified as an "Ohio bank." Any bank that has at least one percent of its deposits located in any of the other 13 states that had introduced some type of anti-union legislation, and is not already classified as a "Wisconsin" or an "Ohio" bank, is classified as a "13 other anti-union states" banks. All other banks include banks with no more than $1 \%$ of their deposits in any of the 15 anti-union states.

\begin{tabular}{|c|c|c|c|c|c|}
\hline Variable & Mean & Median & $\begin{array}{l}\text { Standard } \\
\text { Deviation }\end{array}$ & Minimum & Maximum \\
\hline \multicolumn{6}{|l|}{ Total assets (in millions of \$): } \\
\hline Wisconsin banks & $97,132.48$ & $26,470.50$ & $209,423.90$ & $2,212.79$ & $614,330.37$ \\
\hline Ohio banks & $160,468.26$ & $5,366.27$ & $579,095.08$ & 554.70 & $2,948,432.38$ \\
\hline 13 anti-union state banks & $70,212.19$ & $3,514.66$ & $372,264.12$ & 227.61 & $3,355,609.60$ \\
\hline All other banks & $8,599.40$ & $2,236.30$ & $34,164.48$ & 247.62 & $393,610.69$ \\
\hline
\end{tabular}

Tier I capital ratio (\%):

Wisconsin banks

Ohio banks

$\begin{array}{lllll}11.38 & 10.84 & 1.86 & 9.17 & 15.10 \\ 11.89 & 11.99 & 2.60 & 6.34 & 18.47 \\ 12.57 & 12.65 & 3.25 & 2.37 & 22.00 \\ 12.45 & 12.14 & 3.45 & 1.24 & 25.56\end{array}$

All other banks

$12.45-12.14$

Municipal securities to total assets (\%):

Wisconsin banks 3.01

Ohio banks

3.96

2.61

2.44

0.45

7.55

13 anti-union state banks

3.10

3.05

4.07

0.00

17.22

All other banks

4.72

3.21

3.65

0.00

24.96

$\begin{array}{lll}4.77 & 0.00 & 25.38\end{array}$

Municipal securities to tier I capital (\%):

$\begin{array}{llllll}\text { Wisconsin banks } & 48.51 & 34.32 & 41.11 & 8.22 & 102.91 \\ \text { Ohio banks } & 51.02 & 35.99 & 42.44 & 0.04 & 169.29 \\ 13 \text { anti-union state banks } & 40.09 & 23.22 & 45.90 & 0.00 & 249.64 \\ \text { All other banks } & 58.51 & 41.72 & 57.29 & 0.00 & 308.07\end{array}$

Amount of deposits held in the state of Wisconsin to total deposits (\%):

$\begin{array}{lrrrrr}\text { Wisconsin banks } & 27.27 & 10.11 & 37.05 & 1.59 & 100.00 \\ \text { Ohio banks } & 0.06 & 0.00 & 0.23 & 0.00 & 0.91 \\ 13 \text { anti-union state banks } & 0.01 & 0.00 & 0.05 & 0.00 & 0.46 \\ \text { All other banks } & 0.00 & 0.00 & 0.00 & 0.00 & 0.00\end{array}$

Amount of deposits held in the state of Ohio to total deposits (\%):

\begin{tabular}{|c|c|c|c|c|c|}
\hline Wisconsin banks & 2.17 & 0.00 & 4.59 & 0.00 & 12.85 \\
\hline Ohio banks & 46.28 & 43.03 & 39.10 & 1.13 & 100.00 \\
\hline 13 anti-union state banks & 0.01 & 0.00 & 0.08 & 0.00 & 0.98 \\
\hline All other banks & 0.01 & 0.00 & 0.07 & 0.00 & 0.8 \\
\hline
\end{tabular}

Amount of assets held in any of the other 13 anti-union states to total deposits (\%):

\begin{tabular}{lrrrrr} 
Wisconsin banks & 22.65 & 15.52 & 27.88 & 0.00 & 81.37 \\
Ohio banks & 16.56 & 1.08 & 25.63 & 0.00 & 88.19 \\
13 anti-union state banks & 69.26 & 97.55 & 38.20 & 1.06 & 100.00 \\
All other banks & 0.01 & 0.00 & 0.07 & 0.00 & 0.84 \\
\hline
\end{tabular}




\section{Table 3}

\section{Major announcements and announcement dates associated with Wisconsin's and Ohio's anti-union rights bill}

This table lists major dates related to the passage and implementation of Wisconsin's and Ohio's anti-union rights bill. News items pertaining to the changes in regulations are compiled by examining articles retrieved from a Google search using the keywords Wisconsin union (antiunion) bill, Ohio union (anti-union) bill, states with anti-union bills, and anti-union legislation. For each event, the table also lists our anticipated announcement period stock price reaction for the sample banks.

\begin{tabular}{|c|c|c|c|}
\hline Event & Date & Description & $\begin{array}{c}\text { Hypothesized } \\
\text { inouncement effect }\end{array}$ \\
\hline 1 & December 7, 2010 & $\begin{array}{l}\text { Governor-elect Walker raises possibility of changing state } \\
\text { law to decertify unions and cut state employee benefits }\end{array}$ & + \\
\hline 2 & February 1, 2011 & Bill 5 introduced in the Ohio Senate & + \\
\hline 3 & February 2, 2011 & Governor Walker targets state worker benefits in speech & + \\
\hline 4 & February 17, 2011 & Bill clears committee/Democratic lawmakers leave state & $+/-$ \\
\hline 5 & February 24, 2011 & Assembly ready to vote & + \\
\hline 6 & March 2, 2011 & Ohio Senate approves union bill & + \\
\hline 7 & March 9, 2011 & Assembly passes bill & + \\
\hline 8 & March 11, 2011 & Governor Walker signs bill into law & + \\
\hline 9 & March 16, 2011 & Law challenge filed & - \\
\hline 10 & March 18, 2011 & Wisconsin state judge puts law on hold & - \\
\hline 11 & March 25, 2011 & Wisconsin union law published despite court order & + \\
\hline 12 & March 29, 2011 & Ohio union bill approved by House panel & + \\
\hline 13 & March 30, 2011 & Ohio union bill approved by House and Senate & + \\
\hline 14 & March 31, 2011 & $\begin{array}{l}\text { Wisconsin judge rules union busting bill not in effect } \\
\text { Ohio union bill signed into law }\end{array}$ & $\begin{array}{l}- \\
+\end{array}$ \\
\hline 15 & April 15, 2011 & $\begin{array}{l}\text { Ohio Attorney General certified summary language for } \\
\text { a referendum seeking repeal of Senate Bill } 5 .\end{array}$ & - \\
\hline 16 & May 27, 2011 & Wisconsin union bargaining law struck down & - \\
\hline 17 & June 15, 2011 & Wisconsin Supreme Court rejects ruling that invalidated union law & + \\
\hline 18 & June 29, 2011 & $\begin{array}{l}\text { Wisconsin anti-union law goes into effect } \\
\text { Ohio opponents submit signatures needed to get repeal of bill } \\
\text { on November ballot }\end{array}$ & $+/-$ \\
\hline 19 & July 21,2011 & Ohio puts repeal of anti-union bill on November ballot & - \\
\hline 20 & November 8, 2011 & Ohio voters repeal new law that would limit bargaining rights & - \\
\hline
\end{tabular}




\section{Table 4}

\section{Cumulative abnormal returns around major news announcements associated with the passage of anti-union legislation}

This table presents three-day CARs for announcements associated with the passage of anti-union legislation in Wisconsin and Ohio. We construct cumulative abnormal returns for each event from a Fama-French three factor model (Fama and French 1993). Since not all public banks trade regularly, we add additional leading and lagging market excess return factors to control nonsynchronous trading effects (Dimson 1979). Any bank that has at least one percent of its deposits located in Wisconsin is classified as a "Wisconsin bank." Any bank that has at least one percent of its deposits located in Ohio, and is not already classified as a "Wisconsin" bank, is classified as an "Ohio bank." Any bank that has at least one percent of its deposits located in any of the other 13 states that had introduced some type of anti-union legislation, and is not already classified as a "Wisconsin" or an "Ohio" bank, is classified as a "13 other anti-union states" banks. Non-anti-union state banks include banks with no more than $1 \%$ of their deposits in any of the 15 anti-union states. * p-value $<10 \%$, ** p-value $<5 \%$, *** p-value $<1 \%$.

\begin{tabular}{|c|c|c|c|c|c|c|c|c|c|}
\hline \multirow[b]{2}{*}{ Event } & \multicolumn{3}{|c|}{$\underline{\text { Wisconsin banks }}$} & \multicolumn{2}{|c|}{ Ohio banks } & \multicolumn{2}{|c|}{$\underline{13 \text { other anti-union states }}$} & \multicolumn{2}{|c|}{ All other states } \\
\hline & Date & Average CAR $(\%)$ & t-stat & Average CAR $(\%)$ & t-stat & Average CAR $(\%)$ & t-stat & Average CAR $(\%)$ & t-stat \\
\hline 1 & $12 / 7 / 2010$ & -0.18 & -0.24 & 0.83 & 1.43 & 0.25 & 0.59 & -0.15 & -0.44 \\
\hline 2 & $2 / 1 / 2011$ & 0.01 & 0.01 & -1.86 & -1.00 & $-1.59 * * *$ & -3.08 & 0.04 & 0.09 \\
\hline 3 & $2 / 2 / 2011$ & -0.28 & -0.45 & -2.12 & -1.31 & -0.67 & -1.16 & 0.20 & 0.43 \\
\hline 4 & $2 / 17 / 2011$ & -0.73 & -1.15 & $-1.51 * *$ & -2.59 & $-1.20 * * *$ & -3.74 & -0.25 & -0.73 \\
\hline 5 & $2 / 24 / 2011$ & -1.86 & -1.77 & -0.52 & -1.08 & -0.26 & -0.48 & 0.44 & 0.55 \\
\hline 6 & $3 / 2 / 2011$ & 1.46 & 0.91 & 0.08 & 0.12 & $-0.86 * * *$ & -2.84 & $-0.55 * *$ & -2.12 \\
\hline 7 & $3 / 9 / 2011$ & 1.01 & 0.91 & 0.28 & 0.23 & 0.07 & 0.22 & 0.14 & 0.46 \\
\hline 8 & $3 / 11 / 2011$ & -1.18 & -0.83 & -0.28 & -0.58 & -0.08 & -0.26 & -0.18 & -0.61 \\
\hline 9 & $3 / 16 / 2011$ & -0.07 & -0.14 & -0.19 & -0.42 & -0.37 & -0.67 & -0.46 & -1.55 \\
\hline 10 & $3 / 18 / 2011$ & -0.37 & -0.37 & $-1.36 * * *$ & -2.92 & $-1.06 * *$ & -2.30 & $-0.52 *$ & -1.93 \\
\hline 11 & $3 / 25 / 2011$ & -0.33 & -0.89 & 0.16 & 0.34 & $-0.86^{* *}$ & -2.27 & -0.07 & -0.22 \\
\hline 12 & $3 / 29 / 2011$ & 0.17 & 0.24 & -0.35 & -0.80 & $-0.75^{* *}$ & -2.14 & -0.08 & -0.15 \\
\hline 13 & $3 / 30 / 2011$ & 0.78 & 0.09 & 0.66 & 0.54 & -0.42 & -0.48 & 0.00 & 0.85 \\
\hline 14 & $3 / 31 / 2011$ & 0.42 & 0.49 & 1.03 & 1.54 & 0.00 & 0.00 & 0.33 & 1.20 \\
\hline 15 & $4 / 15 / 2011$ & 0.32 & 0.97 & -1.51 & -1.07 & -0.41 & -0.95 & -0.58 & -1.65 \\
\hline 16 & $5 / 27 / 2011$ & -0.52 & -0.64 & -0.55 & -1.24 & 0.63 & 1.18 & $-0.98 * * *$ & -3.15 \\
\hline 17 & $6 / 15 / 2011$ & -0.85 & -0.91 & 0.70 & 1.34 & -0.14 & -0.27 & 0.38 & 1.19 \\
\hline 18 & $6 / 29 / 2011$ & 1.81 & 0.72 & $-1.23 * * *$ & -3.18 & 0.51 & 0.81 & -0.39 & -1.04 \\
\hline 19 & $7 / 21 / 2011$ & 0.59 & 0.64 & -0.79 & -2.07 & 0.28 & 0.67 & -0.36 & -1.10 \\
\hline 20 & $11 / 8 / 2011$ & 0.00 & 0.00 & -0.03 & -0.06 & $-0.87 * *$ & -2.08 & 0.07 & 0.21 \\
\hline
\end{tabular}




\section{Table 5}

\section{Pooled regression results of stock price reaction to major news announcements associated with the passage of anti-union legislation}

This table presents regression results for announcements associated with the passage of anti-union legislation in Wisconsin and Ohio. We test hypothesis 1 by pooling cross-sectional event data. Since different events associate with varying signed predictions, we sign our test proxy according to the signed predictions of each event within the sample. The model is:

$C A R_{i, t}=\alpha+\delta_{1} \ln \left(\right.$ assets $\left._{i, t}\right)+\delta_{2} \ln \left(1+\right.$ tier I capital ratio $\left._{i, t}\right)+\delta_{3}$ Municipals to tier I capital $_{i, t}+\delta_{4}$ Deposits held in Wisconsin to total deposits $s_{\mathrm{i}, t}+\delta_{5}$ Deposits held in Ohio to total deposits $s_{i, t}+\delta_{6}$ Deposits held in any of the other 13 anti-union states to total deposits $s_{i, t}+\varepsilon_{i, t}$,

where $i$ and $t$ index banks and events, and the $\delta_{1}, \delta_{2}$, and $\delta_{3}$ factors are lagged by one year. $C A R_{i, t}$ is the three-day cumulative abnormal return around an event except for March 30, 2011 where $C A R_{i, t}$ is the fiveday cumulative abnormal return used to span event days. Regression 1 isolates the impact of anti-union legislation on Wisconsin banks; any bank that has at least one percent of its deposits located in Wisconsin. Regression 2 isolates the impact of anti-union legislation on Ohio banks; any bank that has at least one percent of its deposits located in Ohio, and is not already classified as a "Wisconsin" bank. Regression 3 reports the combined impact of anti-union legislation on Wisconsin and Ohio banks. Regression 4 reports the impact of anti-union legislation on the other 13 anti-union state banks; any bank that has at least one percent of its deposits located in any of the other 13 states that had introduced some type of anti-union legislation, and is not already classified as a "Wisconsin" or an "Ohio" bank. Non-anti-union state banks include banks with no more than $1 \%$ of their deposits in any of the 15 anti-union states. Standard errors are clustered by event dates and bank-state. t-statistics are reported in parenthesis. $* p$-value $<10 \%, * * p$ value $<5 \%$, *** p-value $<1 \%$.

\begin{tabular}{|c|c|c|c|c|}
\hline All Banks & \multicolumn{4}{|c|}{ All 20 events } \\
\hline $\begin{array}{l}\text { Dep. Var.: 3-day CAR } \\
\text { (3-factor model, } 1 \text { lead-lag, } 6 \text { mo pre-period) }\end{array}$ & (1) & (2) & (3) & (4) \\
\hline $\ln$ (assets) & $\begin{array}{l}-0.012 * * \\
(-2.185)\end{array}$ & $\begin{array}{l}-0.012 * * \\
(-2.185)\end{array}$ & $\begin{array}{l}-0.012 * * \\
(-2.193)\end{array}$ & $\begin{array}{l}-0.012 * * \\
(-2.191)\end{array}$ \\
\hline $\ln (1+\operatorname{tier} I)$ & $\begin{array}{l}0.014 * * \\
(2.179)\end{array}$ & $\begin{array}{l}0.014 * * \\
(2.181)\end{array}$ & $\begin{array}{l}0.014 * * \\
(2.188)\end{array}$ & $\begin{array}{l}0.014 * * \\
(2.188)\end{array}$ \\
\hline Municipal to tier I ratio & $\begin{array}{c}0.003^{*} \\
(1.773)\end{array}$ & $\begin{array}{r}0.003^{*} \\
(1.782)\end{array}$ & $\begin{array}{c}0.003^{*} \\
(1.781)\end{array}$ & $\begin{array}{c}0.003 * \\
(1.738)\end{array}$ \\
\hline Deposits held in WI to total deposits & $\begin{array}{l}0.008^{* * *} \\
(4.811)\end{array}$ & & & \\
\hline Deposits held in $\mathrm{OH}$ to total deposits & & $\begin{array}{l}0.003 * * * \\
(3.315)\end{array}$ & & \\
\hline Deposits held in WI or OH to total deposits & & & $\begin{array}{l}0.004 * * * \\
(8.120)\end{array}$ & \\
\hline Deposits held in 13 states to total deposits & & & & $\begin{array}{c}-0.001 \\
(-0.767)\end{array}$ \\
\hline Constant & $\begin{array}{c}-0.002 \\
(-0.204)\end{array}$ & $\begin{array}{c}-0.002 \\
(-0.217) \\
\end{array}$ & $\begin{array}{c}-0.002 \\
(-0.212) \\
\end{array}$ & $\begin{array}{c}-0.002 \\
(-0.182)\end{array}$ \\
\hline $\mathrm{R}^{2}$ & 0.00903 & 0.00900 & 0.00913 & 0.00914 \\
\hline $\mathrm{N}$ & 6310 & 6310 & 6310 & 6310 \\
\hline
\end{tabular}


Table 6

Regression results of stock price reaction to eight major news announcements associated with the passage of anti-union legislation

This table presents regression results for announcements associated with the passage of anti-union legislation in Wisconsin and Ohio. We construct cumulative abnormal returns for each event from a Fama-French three factor model (Fama and French 1993). Since not all public banks trade regularly, we add additional leading and lagging market excess return factors to control nonsynchronous trading effects (Dimson 1979). For each event $t$ and each bank $i$ we run various forms of the following regression:

$C A R_{i}=\alpha+\delta_{1} \ln \left(\right.$ assets $\left._{i}\right)+\delta_{2} \ln \left(1+\right.$ tier I capital ratio $\left._{i}\right)+\delta_{3}$ Municipals to tier I capital $_{i}+\delta_{4}$ Deposits held in Wisconsin to total deposits $_{\mathrm{i}}+\delta_{5}$ Deposits held in Ohio to total deposits $s_{i}+\delta_{6}$ Deposits held in any of the other 13 anti-union states to total deposits ${ }_{i}+\varepsilon$

Regression 1 isolates the impact of anti-union legislation on Wisconsin banks; any bank that has at least one percent of its deposits located in Wisconsin. Regression 2 isolates the impact of anti-union legislation on Ohio banks; any bank that has at least one percent of its deposits located in Ohio, and is not already classified as a "Wisconsin" bank. Regression 3 reports the impact of anti-union legislation on the other 13 anti-union state banks; any bank that has at least one percent of its deposits located in any of the other 13 states that had introduced some type of anti-union legislation, and is not already classified as a "Wisconsin" or an "Ohio" bank. Non-anti-union state banks include banks with no more than $1 \%$ of their deposits in any of the 15 anti-union states. Standard errors are clustered by bank-state. t-statistics are reported in parenthesis. * p-value $<10 \%, * * p$-value $<5 \%$, *** p-value $<1 \%$.

\begin{tabular}{|c|c|c|c|c|c|c|}
\hline & \multicolumn{3}{|c|}{ February 1, 2011} & \multicolumn{3}{|c|}{ February 17, 2011} \\
\hline $\begin{array}{l}\text { Dep. Var.: 3-day CAR } \\
\text { (3-factor model, } 1 \text { lead-lag, } 6 \text { mo pre-period) }\end{array}$ & $(1)$ & $(2)$ & (3) & (1) & $(2)$ & (3) \\
\hline \multirow[t]{2}{*}{$\ln$ (assets) } & $-0.050 * * *$ & $-0.050 * * *$ & $-0.050 * * *$ & $-0.021 * *$ & $-0.021 * *$ & $-0.022 * *$ \\
\hline & $(-3.342)$ & $(-3.416)$ & $(-3.591)$ & $(-2.461)$ & $(-2.397)$ & $(-2.431)$ \\
\hline \multirow[t]{2}{*}{$\ln (1+\operatorname{tier} I)$} & $0.054 * * *$ & $0.055 * * *$ & $0.054 * * *$ & $0.019 *$ & $0.019 *$ & $0.019 *$ \\
\hline & $(3.173)$ & $(3.244)$ & $(3.398)$ & $(1.954)$ & $(1.904)$ & $(1.928)$ \\
\hline \multirow[t]{2}{*}{ Municipal to tier I ratio } & $0.007 *$ & $0.007 *$ & 0.005 & 0.004 & 0.004 & 0.003 \\
\hline & $(1.794)$ & $(1.826)$ & $(1.478)$ & $(1.172)$ & $(1.179)$ & $(0.956)$ \\
\hline \multirow[t]{2}{*}{ Deposits held in WI to total deposits } & $0.022 * * *$ & & & $0.026 * * *$ & & \\
\hline & $(3.405)$ & & & $(6.738)$ & & \\
\hline \multirow[t]{2}{*}{ Deposits held in $\mathrm{OH}$ to total deposits } & & $0.022 * * *$ & & & -0.006 & \\
\hline & & $(4.126)$ & & & $(-1.527)$ & \\
\hline \multirow[t]{2}{*}{ Deposits held in 13 states to total deposits } & & & $-0.014 *$ & & & -0.008 \\
\hline & & & $(-2.008)$ & & & $(-1.274)$ \\
\hline \multirow[t]{2}{*}{ Constant } & $0.062 * *$ & $0.062 * *$ & $0.071 * * *$ & $0.076 * * *$ & $0.075 * * *$ & $0.080 * * *$ \\
\hline & $(2.278)$ & $(2.248)$ & $(2.734)$ & $(3.217)$ & $(3.168)$ & $(3.315)$ \\
\hline $\mathrm{R}^{2}$ & 0.0829 & 0.0861 & 0.0914 & 0.0581 & 0.0567 & 0.0630 \\
\hline $\mathrm{N}$ & 319 & 319 & 319 & 319 & 319 & 319 \\
\hline
\end{tabular}


March 2, 2011

March 9, 2011

\begin{tabular}{|c|c|c|c|c|c|c|}
\hline $\begin{array}{l}\text { Dep. Var.: 3-day CAR } \\
\text { (3-factor model, } 1 \text { lead-lag, } 6 \text { mo pre-period) }\end{array}$ & (1) & (2) & (3) & (1) & (2) & (3) \\
\hline Municipal to tier I ratio & $\begin{array}{c}0.002 \\
(0.912)\end{array}$ & $\begin{array}{c}0.002 \\
(0.922)\end{array}$ & $\begin{array}{c}0.002 \\
(0.771)\end{array}$ & $\begin{array}{r}0.005^{*} \\
(1.697)\end{array}$ & $\begin{array}{l}0.005^{*} \\
(1.702)\end{array}$ & $\begin{array}{c}0.005 \\
(1.544)\end{array}$ \\
\hline Deposits held in WI to total deposits & $\begin{array}{l}0.026 * * \\
(2.129)\end{array}$ & & & $\begin{array}{c}0.012 \\
(1.546)\end{array}$ & & \\
\hline Deposits held in $\mathrm{OH}$ to total deposits & & $\begin{array}{r}0.004 * \\
(1.799)\end{array}$ & & & $\begin{array}{l}0.020^{* * *} \\
(6.083)\end{array}$ & \\
\hline Deposits held in 13 states to total deposits & & & $\begin{array}{l}-0.005 \\
(-1.214)\end{array}$ & & & $\begin{array}{c}-0.004 \\
(-1.111)\end{array}$ \\
\hline Constant & $\begin{array}{r}0.015 \\
(1.034)\end{array}$ & $\begin{array}{c}0.014 \\
(0.983)\end{array}$ & $\begin{array}{c}0.017 \\
(1.270)\end{array}$ & $\begin{array}{l}-0.038 * * \\
(-2.240)\end{array}$ & $\begin{array}{l}-0.037 * * \\
(-2.207)\end{array}$ & $\begin{array}{l}-0.035^{* *} \\
(-2.112)\end{array}$ \\
\hline
\end{tabular}

\begin{tabular}{lccc} 
& \multicolumn{3}{c}{ March 25, 2011 } \\
\hline \hline Dep. Var.: 3-day CAR & & & \\
(3-factor model, 1 lead-lag, 6 mo pre-period) & $(1)$ & $(2)$ & $(3)$ \\
\hline $\ln$ (assets) & 0.008 & 0.007 & 0.007 \\
& $(0.599)$ & $(0.550)$ & $(0.560)$ \\
$\ln (1+$ tier I) & -0.007 & -0.007 & -0.007 \\
& $(-0.498)$ & $(-0.455)$ & $(-0.475)$ \\
Municipal to tier I ratio & -0.002 & -0.002 & -0.003 \\
& $(-0.542)$ & $(-0.540)$ & $(-0.752)$ \\
Deposits held in WI to total deposits & -0.003 & & \\
& $(-0.961)$ & & \\
Deposits held in OH to total deposits & & $0.017^{* * * *}$ & \\
& & $(4.740)$ & -0.007 \\
Deposits held in 13 states to total deposits & & & $(-1.462)$ \\
& & -0.021 \\
Constant & $-0.025^{*}$ & $-0.025^{*}$ & $(-1.560)$ \\
\hline $\mathrm{R}^{2}$ & $-1.898)$ & $(-1.862)$ & 0.0106 \\
$\mathrm{~N}$ & 0.00546 & 0.0105 & 318 \\
\hline \hline
\end{tabular}




\begin{tabular}{|c|c|c|c|c|c|c|}
\hline & \multicolumn{3}{|c|}{ March 30, 2011} & \multicolumn{3}{|c|}{ March 30, 2011} \\
\hline $\begin{array}{l}\text { Dep. Var.: 3-day CAR } \\
\text { (3-factor model, } 1 \text { lead-lag, } 6 \text { mo pre-period) }\end{array}$ & $(1)$ & (2) & (3) & $\begin{array}{l}\text { Dep. Var.: 5-day }( \\
(1)\end{array}$ & $(2)$ & (3) \\
\hline $\ln ($ assets $)$ & $\begin{array}{c}-0.015 \\
(-1.199)\end{array}$ & $\begin{array}{c}-0.015 \\
(-1.198)\end{array}$ & $\begin{array}{c}-0.016 \\
(-1.233)\end{array}$ & $\begin{array}{l}-0.015 \\
(-1.343)\end{array}$ & $\begin{array}{c}-0.016 \\
(-1.373)\end{array}$ & $\begin{array}{c}-0.016 \\
(-1.445)\end{array}$ \\
\hline $\ln (1+\operatorname{tier} I)$ & $\begin{array}{c}0.017 \\
(1.146)\end{array}$ & $\begin{array}{c}0.017 \\
(1.143)\end{array}$ & $\begin{array}{c}0.018 \\
(1.172)\end{array}$ & $\begin{array}{c}0.022 \\
(1.604)\end{array}$ & $\begin{array}{l}0.022 \\
(1.630)\end{array}$ & $\begin{array}{c}0.022 * \\
(1.721)\end{array}$ \\
\hline Municipal to tier I ratio & $\begin{array}{c}0.000 \\
(0.096)\end{array}$ & $\begin{array}{c}0.000 \\
(0.094)\end{array}$ & $\begin{array}{l}-0.000 \\
(-0.019)\end{array}$ & $\begin{array}{l}0.005 \\
(1.611)\end{array}$ & $\begin{array}{c}0.005 \\
(1.631)\end{array}$ & $\begin{array}{c}0.004 \\
(1.423)\end{array}$ \\
\hline Deposits held in WI to total deposits & $\begin{array}{l}-0.010 * * * \\
(-2.763)\end{array}$ & & & $\begin{array}{c}0.002 \\
(0.313)\end{array}$ & & \\
\hline Deposits held in $\mathrm{OH}$ to total deposits & & $\begin{array}{c}0.002 \\
(0.377)\end{array}$ & & & $\begin{array}{l}0.013 * * * \\
(3.045)\end{array}$ & \\
\hline Deposits held in 13 states to total deposits & & & $\begin{array}{l}-0.005 \\
(-0.655)\end{array}$ & & & $\begin{array}{l}-0.013 \\
(-1.418)\end{array}$ \\
\hline Constant & $\begin{array}{r}0.015 \\
(0.781) \\
\end{array}$ & $\begin{array}{r}0.015 \\
(0.803) \\
\end{array}$ & $\begin{array}{c}0.018 \\
(1.071)\end{array}$ & $\begin{array}{l}-0.046^{*} \\
(-2.008)\end{array}$ & $\begin{array}{l}-0.046 * \\
(-2.009)\end{array}$ & $\begin{array}{l}-0.038 \\
(-1.681)\end{array}$ \\
\hline $\mathrm{R}^{2}$ & 0.0134 & 0.0133 & 0.0150 & 0.0514 & 0.0540 & 0.0669 \\
\hline \multirow[t]{2}{*}{$\mathrm{N}$} & 318 & 318 & 318 & 318 & 318 & 318 \\
\hline & & y 27,201 & \multicolumn{4}{|c|}{ June 29,2011} \\
\hline $\begin{array}{l}\text { Dep. Var.: 3-day CAR } \\
\text { (3-factor model, } 1 \text { lead-lag, } 6 \text { mo pre-period) }\end{array}$ & (1) & $(2)$ & $(3)$ & $(1)$ & (2) & (3) \\
\hline $\ln ($ assets $)$ & $\begin{array}{c}-0.005 \\
(-0.446)\end{array}$ & $\begin{array}{c}-0.005 \\
(-0.458)\end{array}$ & $\begin{array}{c}-0.004 \\
(-0.372)\end{array}$ & $\begin{array}{c}0.018 \\
(1.181)\end{array}$ & $\begin{array}{c}0.020 \\
(1.256)\end{array}$ & $\begin{array}{c}0.020 \\
(1.249)\end{array}$ \\
\hline $\ln (1+\operatorname{tier} \mathrm{I})$ & $\begin{array}{c}0.005 \\
(0.422)\end{array}$ & $\begin{array}{c}0.005 \\
(0.432)\end{array}$ & $\begin{array}{c}0.005 \\
(0.361)\end{array}$ & $\begin{array}{l}-0.025 \\
(-1.391)\end{array}$ & $\begin{array}{l}-0.027 \\
(-1.438)\end{array}$ & $\begin{array}{c}-0.027 \\
(-1.428)\end{array}$ \\
\hline Municipal to tier I ratio & $\begin{array}{c}-0.001 \\
(-0.316)\end{array}$ & $\begin{array}{c}-0.001 \\
(-0.316)\end{array}$ & $\begin{array}{c}-0.000 \\
(-0.038)\end{array}$ & $\begin{array}{l}-0.014 * * * \\
(-2.772)\end{array}$ & $\begin{array}{l}-0.014 * * * \\
(-2.754)\end{array}$ & $\begin{array}{l}-0.013 \text { *** } \\
(-2.741)\end{array}$ \\
\hline Deposits held in WI to total deposits & $\begin{array}{l}-0.011 * \\
(-1.996)\end{array}$ & & & $\begin{array}{c}0.118 * * * \\
(14.736)\end{array}$ & & \\
\hline Deposits held in $\mathrm{OH}$ to total deposits & & $\begin{array}{c}0.002 \\
(0.482)\end{array}$ & & & $\begin{array}{l}-0.012 * * \\
(-2.150)\end{array}$ & \\
\hline Deposits held in 13 states to total deposits & & & $\begin{array}{c}0.009 \\
(1.042)\end{array}$ & & & $\begin{array}{c}0.007 \\
(0.845)\end{array}$ \\
\hline Constant & $\begin{array}{c}0.007 \\
(0.298)\end{array}$ & $\begin{array}{c}0.008 \\
(0.316)\end{array}$ & $\begin{array}{c}0.002 \\
(0.069)\end{array}$ & $\begin{array}{l}0.052 * * \\
(2.034)\end{array}$ & $\begin{array}{c}0.048 * \\
(1.893)\end{array}$ & $\begin{array}{c}0.044 * \\
(1.793)\end{array}$ \\
\hline $\mathrm{R}^{2}$ & 0.00147 & 0.00126 & 0.00693 & 0.0605 & 0.0414 & 0.0427 \\
\hline $\mathrm{N}$ & 311 & 311 & 311 & 308 & 308 & 308 \\
\hline
\end{tabular}


Table 7

\section{Pooled regression results of stock price reaction to eight major news announcements associated with the passage of anti-union legislation}

This table presents regression results for announcements associated with the passage of anti-union legislation in Wisconsin and Ohio. We test hypothesis 1 by pooling cross-sectional event data. Since different events associate with varying signed predictions, we sign our test proxy according to the signed predictions of each event within the sample. The model is:

$C A R_{i, t}=\alpha+\delta_{1} \ln \left(\right.$ assets $\left._{i, t}\right)+\delta_{2} \ln \left(1+\right.$ tier I capital ratio r $\left._{i, t}\right)+\delta_{3}$ Municipals to tier I capital $_{i, t}+\delta_{4}$ Deposits held in Wisconsin to total deposits $\mathrm{s}_{\mathrm{i}, t}+\delta_{5}$ Deposits held in Ohio to total deposits $s_{i, t}+\delta_{6}$ Deposits held in any of the other 13 anti-union states to total deposits ${ }_{i, t}+\varepsilon_{i, t}$,

where $i$ and $t$ index banks and events, and the $\delta_{1}, \delta_{2}$, and $\delta_{3}$ factors are lagged by one year. $C A R_{i, t}$ is the three-day cumulative abnormal return around an event except for March 30, 2011 where $C A R_{i, t}$ is the five-day cumulative abnormal return used to span event dates. Regression 1 isolates the impact of anti-union legislation on Wisconsin banks; any bank that has at least one percent of its deposits located in Wisconsin. Regression 2 isolates the impact of anti-union legislation on Ohio banks; any bank that has at least one percent of its deposits located in Ohio, and is not already classified as a "Wisconsin" bank. Regression 3 reports the combined impact of anti-union legislation on Wisconsin and Ohio banks. Regression 4 reports the impact of anti-union legislation on the other 13 anti-union state banks; any bank that has at least one percent of its deposits located in any of the other 13 states that had introduced some type of anti-union legislation, and is not already classified as a "Wisconsin" or an "Ohio" bank. Non-anti-union state banks include banks with no more than $1 \%$ of their deposits in any of the 15 anti-union states. Standard errors are clustered by event and bank-state t-statistics are reported in parenthesis. $t$ statistics are reported in parentheses. $* p$-value $<10 \%$, ** p-value $<5 \%$, ***p-value $<1 \%$.

\begin{tabular}{|c|c|c|c|c|}
\hline All Banks & & ajor events & & \\
\hline $\begin{array}{l}\text { Dep. Var.: 3-day CAR } \\
\text { (3-factor model, } 1 \text { lead-lag, } 6 \text { mo pre-period) }\end{array}$ & (1) & (2) & (3) & (4) \\
\hline $\ln$ (assets) & $\begin{array}{l}-0.013 * * \\
(-2.109)\end{array}$ & $\begin{array}{l}-0.013^{* *} \\
(-2.126)\end{array}$ & $\begin{array}{l}-0.013 * * \\
(-2.137)\end{array}$ & $\begin{array}{l}-0.013^{* *} \\
(-2.127)\end{array}$ \\
\hline $\ln (1+$ tier I $)$ & $\begin{array}{l}0.014 * * \\
(2.046)\end{array}$ & $\begin{array}{l}0.014 * * \\
(2.069)\end{array}$ & $\begin{array}{l}0.014 * * \\
(2.080)\end{array}$ & $\begin{array}{l}0.014 * * \\
(2.074)\end{array}$ \\
\hline Municipal to tier I ratio & $\begin{array}{c}0.001 \\
(0.565)\end{array}$ & $\begin{array}{c}0.001 \\
(0.583)\end{array}$ & $\begin{array}{c}0.001 \\
(0.579)\end{array}$ & $\begin{array}{c}0.001 \\
(0.358)\end{array}$ \\
\hline Deposits held in WI to total deposits & $\begin{array}{l}0.026 \text { *** } \\
(10.928)\end{array}$ & & & \\
\hline Deposits held in $\mathrm{OH}$ to total deposits & & $\begin{array}{l}0.008 * * * \\
(5.321)\end{array}$ & & \\
\hline Deposits held in WI or OH to total deposits & & & $\begin{array}{l}0.010 * * * \\
(4.335)\end{array}$ & \\
\hline Deposits held in 13 states to total deposits & & & & $\begin{array}{c}-0.006^{*} \\
(-1.874)\end{array}$ \\
\hline Constant & $\begin{array}{c}0.013 \\
(0.867) \\
\end{array}$ & $\begin{array}{c}0.013 \\
(0.849) \\
\end{array}$ & $\begin{array}{c}0.013 \\
(0.864) \\
\end{array}$ & $\begin{array}{r}0.015 \\
(1.031) \\
\end{array}$ \\
\hline $\mathrm{R}^{2}$ & 0.0103 & 0.0096 & 0.0102 & 0.0122 \\
\hline $\mathrm{N}$ & 2530 & 2530 & 2530 & 2530 \\
\hline
\end{tabular}




\section{Table 8}

\section{Robustness tests using pooled regression results of stock price reaction to major news announcements associated with the passage of anti-union legislation}

This table presents robustness test using pooled regression results for announcements associated with the passage of anti-union legislation in Wisconsin and Ohio. Specifically, we examine the effect of anti-union legislation on banks versus other firms in anti-union states. We collect stock returns of all industrial firms over the period of analysis. We also collect information on the state in which each industrial firm is headquartered and (as a control variable) each firm's leverage ratio (defined as total debt to total assets). Using regressions similar to Equations 1-3 (for but applied to industrial firms), we interact size with state headquarter and with industry fixed effects. Regression 1 isolates the impact of anti-union legislation on industrial firms headquartered in Wisconsin; Regression 2 isolates the impact of anti-union legislation on firms headquartered in Ohio; Regression 3 reports the combined impact of anti-union legislation on firms headquartered in either Wisconsin or Ohio. $t$ statistics are reported in parentheses. * p-value $<10 \%$, ** p-value $<5 \%$, *** p-value $<1 \%$.

\begin{tabular}{lccc}
\hline \hline All Industrials Sample & & & \\
\hline \hline Dep. Var.: 3-day CAR & & & \\
(3-factor model, 1 lead-lag, 6 mo pre-period) & $(1)$ & $(2)$ & $(3)$ \\
\hline $\ln$ (assets) & 0.000 & 0.000 & 0.000 \\
& $(0.486)$ & $(0.486)$ & $(0.488)$ \\
leverage & 0.000 & 0.000 & 0.000 \\
& $(0.127)$ & $(0.127)$ & $(0.128)$ \\
Wisconsin Indicator & -0.000 & & \\
& $(-0.184)$ & & \\
Ohio Indicator & & 0.000 & \\
& & & \\
Wisconsin and Ohio Indicator & & & $-0.0045)$ \\
& & & $-0.322)$ \\
constant & -0.001 & -0.001 & -0.001 \\
& $(-0.591)$ & $(-0.591)$ & $(-0.590)$ \\
\hline & & & \\
$\mathrm{R}^{2}$ & 0.0000403 & 0.0000400 & 0.0000425 \\
$\mathrm{~N}$ & 73513 & 73513 & 73513 \\
\hline \hline
\end{tabular}

*Standard errors clustered by event 


\section{Table 9}

\section{Reaction of municipal spreads to major news announcements associated with the passage of anti- union legislation}

This table presents regression results for daily state-level changes in municipal bond spreads on announcement days associated with the passage of anti-union legislation in Wisconsin and Ohio, relative to spread changes on non-announcement days and spread changes in other states, from 2010 to 2011. For each day $t$ and each state $i$ we run various forms of the following regression:

$\Delta$ Spread $_{i, t}=\alpha+\beta_{1}$ EventIndicator $_{t}+\beta_{2}$ StateIndicator $_{i}+\beta_{3}$ EventIndicator $_{t} *$ StateIndicator $_{i}+e_{i, t}$,

where $\Delta$ Spread $_{i, t}$ are 1-day lead minus 1-day lagged spreads using AAA 10-year general obligation municipal bond rates benchmarked against 10-year Treasury rates, EventIndicator ${ }_{t}$ equals 1 when spread changes are centered around event days and 0 otherwise, and StateIndicator ${ }_{i}$ equals 1 when spread changes come from debt issued by Wisconsin or Ohio, and 0 otherwise. Since different events associate with varying signed predictions, we pool events by assigning a value of -1 to the dependent variable when observation dates correspond to the negative events in Table 3 which lists signed predictions of each event within the sample. The set of events underlying panel A comprises all events listed in Table 3. The set of events underlying panel B comprises the subset of 8 events for which the individual event regressions reported in Table 6 identify statistically significant effects. $t$-statistics are reported in parentheses. $*$ p-value $<10 \%,{ }^{* *} p$-value $<5 \%$, *** $p$-value $<1 \%$.

Panel A: Pooling on all 20 events

\begin{tabular}{|c|c|c|c|c|}
\hline $\begin{array}{l}\text { Dependent Variable: } \\
\Delta \operatorname{Spread}_{i, t}\end{array}$ & (1) & $(2)$ & (3) & (4) \\
\hline Event-date Indicator & $\begin{array}{c}0.0038 * * * \\
(8.711)\end{array}$ & $\begin{array}{c}0.0037 * * * \\
(8.012)\end{array}$ & $\begin{array}{c}0.0038 * * * \\
(8.605)\end{array}$ & $\begin{array}{c}0.0038 * * * \\
(8.605)\end{array}$ \\
\hline Wisconisn Indicator & $\begin{array}{c}-0.0005 * * * \\
(-4.742)\end{array}$ & & & $\begin{array}{c}-0.0005 * * * \\
(-4.701)\end{array}$ \\
\hline Ohio Indicator & & $\begin{array}{c}-0.0003 * * \\
(-2.324)\end{array}$ & & $\begin{array}{l}-0.0003 * * \\
(-2.380)\end{array}$ \\
\hline Wisconsin and Ohio Indicator & & & $\begin{array}{c}-0.0004 * * * \\
(-2.726)\end{array}$ & \\
\hline Event-date Indicator $*$ Wisconisn Indicator & $\begin{array}{l}-0.0074 * * * \\
(-16.894)\end{array}$ & & & $\begin{array}{l}-0.0074 * * * \\
(-16.638)\end{array}$ \\
\hline Event-date Indicator $*$ Ohio Indicator & & $\begin{array}{l}-0.0010^{* *} \\
(-2.271)\end{array}$ & & $\begin{array}{l}-0.0012 * * \\
(-2.673)\end{array}$ \\
\hline Event-date Indicator * Wisconsin and Ohio Indicator & & & $\begin{array}{l}-0.0043 * \\
(-1.899)\end{array}$ & \\
\hline Constant & $\begin{array}{l}0.0021 * * * \\
(18.564)\end{array}$ & $\begin{array}{l}0.0021 * * * \\
(18.457)\end{array}$ & $\begin{array}{l}0.0021 * * * \\
(18.267)\end{array}$ & $\begin{array}{l}0.0021 * * * \\
(18.267)\end{array}$ \\
\hline $\mathrm{R}$-square & 0.000119 & 0.000108 & 0.000116 & 0.000119 \\
\hline $\mathrm{N}$ & 25992 & 25992 & 25992 & 25992 \\
\hline
\end{tabular}

*Standard errors clustered by state 
Panel B: Pooling on the 8 primary events

Dependent Variable:

(1)

(2)

(3)

(4)

$\Delta$ Spread $_{i, t}$

Event-date Indicator

$-0.0080 * * *$

$-0.0080 * * *$

$-0.0079 * * *$

$-0.0079 * * *$

$(-18.027)$

(-18.006)

$(-17.650)$

$(-17.649)$

Wisconisn Indicator

$-0.0008 * * *$

$-0.0008 * * *$

$(-7.330)$

$(-7.249)$

Ohio Indicator

$-0.0003 * *$

$-0.0003 * * *$

$(-2.566)$

(-2.684)

Wisconsin and Ohio Indicator

$-0.0006 * *$

$(-2.597)$

Event-date Indicator * Wisconisn Indicator

$-0.0024 * * *$

$-0.0024 * * *$

$(-5.395)$

$(-5.377)$

Event-date Indicator * Ohio Indicator

$-0.0016 * * *$

$-0.0017 * * *$

(-3.673)

$(-3.727)$

Event-date Indicator * Wisconsin and Ohio Indicator io

\begin{tabular}{lccc} 
& & $-0.0020 * * *$ \\
& & $(-3.922)$ & \\
& & & \\
$0.0024 * * *$ & $0.0024 * * *$ & $0.0024 * * *$ & $0.0024 * * *$ \\
$(22.024)$ & $(21.737)$ & $(21.676)$ & $(21.675)$ \\
\hline 0.000213 & 0.000211 & 0.000213 & 0.000214 \\
25992 & 25992 & 25992 & 25992 \\
\hline
\end{tabular}

*Standard errors clustered by state 


\section{Table 10}

\section{Changes in bank lending and the resolution of state budget constraints.}

This table presents regression results comparing bank-level changes in lending across bank-states. In particular, for the set of publicly traded banks we model the cross-section of changes in total bank loans as a function of banks' presence in Wisconsin and/or Ohio relative to changes in lending by other banks:

$$
\Delta \text { TotalLoans }_{i}=\alpha+\beta_{1} \text { StateIndicator }_{i}+e_{i}
$$

where $\Delta$ TotalLoans $_{i}$ is the change in total loans for bank $i$, and StateIndicator ${ }_{i}$ equals 1 for Wisconsin and/or Ohio banks, and zero otherwise. Column 1 highlights the impact of the extent to which a bank conducts business in Wisconsin (the StateIndicator equals one for any bank that has at least one percent of its deposits located in Wisconsin and zero otherwise). Column 2 highlights the impact of the extent to which a bank conducts business in Ohio (the StateIndicator equals one for any bank that has at least one percent of its deposits located in Ohio, and is not already classified as a "Wisconsin" bank and zero otherwise). Column 3 runs Wisconsin and Ohio effects together. Column 4 reports the combined impact of Wisconsin and Ohio banks. We exclude observations in the extreme top $1 \%$ in changes in total loans to limit the effects of very large banks. Panel A examines relative changes in lending from 2008 through 2011 and panel B measures relative changes in lending from 2008 through 2012. $t$-statistics are reported in parentheses.

$*$ p-value $<10 \%$, ** p-value $<5 \%$, *** p-value $<1 \%$.

Panel A

Dependent Variable:

Changes in Total Loans, 2008 - 2011

(1)

(2)

(3)

(4)

(in thousands of dollars)

WI Indicator 3479898.491**

(2.390)

$\mathrm{OH}$ Indicator

WI/OH combined indicator

$-2353256.937 * * *$

$(-2.619)$
$3307512.662 * *$

(2.293)

$-2256687.225 * *$

$(-2.531)$

$2556784.770 * * *$

\begin{tabular}{lcccc} 
Intercept & -72109.741 & 196845.801 & 100276.088 & 142870.579 \\
& $(-0.301)$ & $(0.803)$ & $(0.407)$ & $(0.604)$ \\
\hline R-square & 0.0189 & 0.0226 & 0.0397 & 0.0385 \\
$\mathrm{~N}$ & 296 & 296 & 296 & 296 \\
\hline \hline
\end{tabular}


Panel B

Dependent Variable:

Changes in Total Loans, 2008 - 2012

(1)

(2)

(3)

(4)

(in thousands of dollars)

WI Indicator

$5840699.290 * * *$

(3.636)
$5695246.070 * * *$

(3.563)

$-1998677.403 * * \quad-1824776.760 *$

$(-1.979) \quad(-1.844)$

$\mathrm{OH}$ Indicator

WI/OH combined indicator

$2933282.146 * * *$

(3.542)

\begin{tabular}{lcccc} 
Intercept & 108581.585 & 427935.448 & 254034.805 & 417706.741 \\
& $(0.403)$ & $(1.522)$ & $(0.909)$ & $(1.552)$ \\
\hline R-square & 0.0445 & 0.0136 & 0.0558 & 0.0423 \\
$\mathrm{~N}$ & 284 & 284 & 284 & 284 \\
\hline \hline
\end{tabular}




\section{References}

Abowd, J.M., 1989. The effect of wage bargains on the stock market value of the firm. American Economic Review 79, 774-800.

Abowd, J.M., and T. Lemieux, 1993. The effects of product market competition on collective bargaining agreements: The case of foreign competition in Canada. Quarterly Journal of Economics 108, 983-1014.

Akhigb, A., and A.D. Martin, 2006. Valuation impact of Sarbanes-Oxley: Evidence from disclosure and governance with the financial services industry. Journal of Banking and Finance 30, 989-1006.

Chen, H., M. Kacperczyk, and H. Ortiz-Molina, 2011. Labor unions, operating flexibility, and the cost of equity. Journal of Financial and Quantitative Analysis 46, 25-58.

Chen, H., M. Kacperczyk, and H. Ortiz-Molina, 2012. Do non-financial stakeholders affect the pricing of risky debt? Evidence from unionized workers, Review of Finance 16, 347-383.

Cornett, M.M., E. Ors, and H. Tehranian, 2002. Bank performance around the introduction of a Section 20 subsidiary. Journal of Finance 57, 501-522.

Cornett, M.M., Z. Razaee, and H. Tehranian, 1996. An investigation of capital market reactions to accounting rules on fair value accounting. Journal of Accounting and Economics 22, 119-154.

Dimson, E., 1979. Risk measurement when shares are subject to infrequent trading. Journal of Financial Economics 6, 197-226.

Faleye, O., V. Mehrotra, and R. Morck, 2009. When labor has a voice in corporate governance. Journal of Financial and Quantitative Analysis 41, 489-510.

Fama, E., and K. R. French, 1993. Common risk factors in the returns on stocks and bonds. Journal of Financial Economics 33, 3-56.

Klasa, S., W.F. Maxwell, and H. Ortiz-Molina, 2009. The strategic use of corporate cash holdings in collective bargaining with labor unions. Journal of Financial Economics 92, 421-442.

Matsa, D.A., 2010. Capital structure as a strategic variable: Evidence from collective bargaining. Journal of Finance 65, 1197-1232.

Naiker, V., and Navissi, F., 2006. Securities price effects of unionization legislation. Journal of Financial Research 29, 63-78. 


\section{Appendix}

\section{Regression results of stock price reaction to other news announcements associated with the passage of anti-union legislation}

This table presents regression results for announcements associated with the passage of anti-union legislation in Wisconsin and Ohio. We construct cumulative abnormal returns for each event from a Fama-French three factor model (Fama and French 1993). Since not all public banks trade regularly, we add additional leading and lagging market excess return factors to control nonsynchronous trading effects (Dimson 1979). For each event $t$ and each bank $i$ we run various forms of the following regression:

$C A R_{i}=\alpha+\delta_{1} \ln \left(\right.$ assets $\left._{i}\right)+\delta_{2} \ln \left(1+\right.$ tier I capital ratio $\left._{i}\right)+\delta_{3}$ Municipals to tier I capital $_{i}+\delta_{4}$ Deposits held in Wisconsin to total deposits $_{\mathrm{i}}+\delta_{5}$ Deposits held in Ohio to total deposits $s_{i}+\delta_{6}$ Deposits held in any of the other 13 anti-union states to total deposits ${ }_{i}+\varepsilon$

Regression 1 isolates the impact of anti-union legislation on Wisconsin banks; any bank that has at least one percent of its deposits located in Wisconsin. Regression 2 isolates the impact of anti-union legislation on Ohio banks; any bank that has at least one percent of its deposits located in Ohio, and is not already classified as a "Wisconsin" bank. Regression 3 reports the impact of anti-union legislation on the other 13 anti-union state banks; any bank that has at least one percent of its deposits located in any of the other 13 states that had introduced some type of anti-union legislation, and is not already classified as a "Wisconsin" or an "Ohio" bank. Non-anti-union state banks include banks with no more than $1 \%$ of their deposits in any of the 15 anti-union states. Standard errors are clustered by bank-state. t-statistics are reported in parenthesis. $* p$-value $<10 \%$, $* * p$-value $<5 \%$, *** p-value $<1 \%$.

\begin{tabular}{|c|c|c|c|c|c|c|}
\hline \multirow[b]{2}{*}{$\begin{array}{l}\text { Dep. Var.: 3-day CAR } \\
\text { (3-factor model, 1lead-lag, 6mo pre-period) }\end{array}$} & \multicolumn{3}{|c|}{ December 7, 2010} & \multicolumn{3}{|c|}{ February 2, 2011} \\
\hline & (1) & (2) & $(3)$ & (1) & (2) & (3) \\
\hline $\ln$ (assets) & $\begin{array}{c}-0.015 \\
(-1.450)\end{array}$ & $\begin{array}{c}-0.015 \\
(-1.441)\end{array}$ & $\begin{array}{c}-0.015 \\
(-1.441)\end{array}$ & $\begin{array}{l}-0.041 * * * \\
(-2.708)\end{array}$ & $\begin{array}{l}-0.041 * * \\
(-2.692)\end{array}$ & $\begin{array}{l}-0.041 * * * \\
(-2.735)\end{array}$ \\
\hline $\ln (1+\operatorname{tier} \mathrm{I})$ & $\begin{array}{c}0.023^{*} \\
(1.801)\end{array}$ & $\begin{array}{c}0.023^{*} \\
(1.790)\end{array}$ & $\begin{array}{c}0.023 * \\
(1.790)\end{array}$ & $\begin{array}{l}0.044 * * \\
(2.511)\end{array}$ & $\begin{array}{l}0.044 * * \\
(2.495)\end{array}$ & $\begin{array}{l}0.044 * * \\
(2.534)\end{array}$ \\
\hline Municipal to tier I ratio & $\begin{array}{l}0.008 * * \\
(2.112)\end{array}$ & $\begin{array}{l}0.008 * * \\
(2.114)\end{array}$ & $\begin{array}{l}0.008 * * \\
(2.174)\end{array}$ & $\begin{array}{c}0.005 \\
(1.074)\end{array}$ & $\begin{array}{c}0.005 \\
(1.073)\end{array}$ & $\begin{array}{c}0.005 \\
(1.006)\end{array}$ \\
\hline Deposits held in WI to total deposits & $\begin{array}{c}0.006 \\
(0.654)\end{array}$ & & & $\begin{array}{c}-0.002 \\
(-0.294)\end{array}$ & & \\
\hline Deposits held in $\mathrm{OH}$ to total deposits & & $\begin{array}{c}0.003 \\
(0.672)\end{array}$ & & & $\begin{array}{c}-0.001 \\
(-0.220)\end{array}$ & \\
\hline Deposits held in 13 states to total deposits & & & $\begin{array}{c}-0.001 \\
(-0.114)\end{array}$ & & & $\begin{array}{c}-0.002 \\
(-0.221)\end{array}$ \\
\hline Constant & $\begin{array}{l}-0.067 * * * \\
(-3.489)\end{array}$ & $\begin{array}{l}-0.067 * * * \\
(-3.500)\end{array}$ & $\begin{array}{l}-0.067 * * * \\
(-3.779)\end{array}$ & $\begin{array}{c}0.059 * \\
(1.996)\end{array}$ & $\begin{array}{c}0.059 * \\
(2.002)\end{array}$ & $\begin{array}{l}0.060 * * \\
(2.054)\end{array}$ \\
\hline $\mathrm{R}^{2}$ & 0.0659 & 0.0659 & 0.0659 & 0.0507 & 0.0507 & 0.0508 \\
\hline $\mathrm{N}$ & 317 & 317 & 317 & 319 & 319 & 319 \\
\hline
\end{tabular}




\begin{tabular}{|c|c|c|c|c|c|c|}
\hline \multirow[b]{2}{*}{$\begin{array}{l}\text { Dep. Var.: 3-day CAR } \\
\text { (3-factor model, 1lead-lag, 6mo pre-period) }\end{array}$} & \multicolumn{3}{|c|}{ February 24,2011} & \multicolumn{3}{|c|}{ March 11, 2011} \\
\hline & $(1)$ & $(2)$ & (3) & $(1)$ & (2) & (3) \\
\hline $\ln$ (assets) & $\begin{array}{c}0.013 \\
(1.572)\end{array}$ & $\begin{array}{c}0.013 \\
(1.603)\end{array}$ & $\begin{array}{c}0.013 \\
(1.548)\end{array}$ & $\begin{array}{c}0.015 \\
(1.675)\end{array}$ & $\begin{array}{c}0.015 \\
(1.681)\end{array}$ & $\begin{array}{c}0.015 \\
(1.667)\end{array}$ \\
\hline $\ln (1+\operatorname{tier} \mathrm{I})$ & $\begin{array}{c}-0.019 * \\
(-1.809)\end{array}$ & $\begin{array}{c}-0.019 * \\
(-1.830)\end{array}$ & $\begin{array}{c}-0.019 * \\
(-1.818)\end{array}$ & $\begin{array}{c}-0.015 \\
(-1.496)\end{array}$ & $\begin{array}{c}-0.015 \\
(-1.506)\end{array}$ & $\begin{array}{c}-0.015 \\
(-1.491)\end{array}$ \\
\hline Municipal to tier I ratio & $\begin{array}{c}-0.004 \\
(-0.898)\end{array}$ & $\begin{array}{c}-0.004 \\
(-0.892)\end{array}$ & $\begin{array}{c}-0.005 \\
(-1.085)\end{array}$ & $\begin{array}{c}-0.002 \\
(-0.617)\end{array}$ & $\begin{array}{c}-0.002 \\
(-0.624)\end{array}$ & $\begin{array}{c}-0.002 \\
(-0.605)\end{array}$ \\
\hline Deposits held in WI to total deposits & $\begin{array}{c}-0.005 \\
(-0.698)\end{array}$ & & & $\begin{array}{c}-0.019 \\
(-1.649)\end{array}$ & & \\
\hline Deposits held in $\mathrm{OH}$ to total deposits & & $\begin{array}{c}-0.015 \\
(-1.645)\end{array}$ & & & $\begin{array}{c}-0.006^{*} \\
(-1.885)\end{array}$ & \\
\hline Deposits held in 13 states to total deposits & & & $\begin{array}{c}-0.009 \\
(-0.842)\end{array}$ & & & $\begin{array}{c}0.000 \\
(0.025)\end{array}$ \\
\hline Constant & $\begin{array}{c}0.041 \\
(1.033)\end{array}$ & $\begin{array}{c}0.041 \\
(1.025)\end{array}$ & $\begin{array}{c}0.048 \\
(1.048)\end{array}$ & $\begin{array}{c}-0.032 * * \\
(-2.545)\end{array}$ & $\begin{array}{l}-0.032^{* *} \\
(-2.506)\end{array}$ & $\begin{array}{l}-0.032 * * \\
(-2.499)\end{array}$ \\
\hline $\mathrm{R}^{2}$ & 0.0122 & 0.0133 & 0.0146 & 0.0222 & 0.0215 & 0.0208 \\
\hline $\mathrm{N}$ & 319 & 319 & 319 & 318 & 318 & 318 \\
\hline
\end{tabular}

\begin{tabular}{|c|c|c|c|c|c|c|}
\hline & \multicolumn{3}{|c|}{ March 16, 2011} & \multicolumn{3}{|c|}{ March 18, 2011} \\
\hline $\begin{array}{l}\text { Dep. Var.: 3-day CAR } \\
\text { (3-factor model, 1lead-lag, 6mo pre-period) }\end{array}$ & (1) & (2) & (3) & (1) & (2) & (3) \\
\hline $\ln$ (assets) & $\begin{array}{c}-0.013 \\
(-1.337)\end{array}$ & $\begin{array}{c}-0.013 \\
(-1.337)\end{array}$ & $\begin{array}{c}-0.013 \\
(-1.340)\end{array}$ & $\begin{array}{l}-0.023 * * \\
(-2.342)\end{array}$ & $\begin{array}{l}-0.022 * * \\
(-2.290)\end{array}$ & $\begin{array}{l}-0.023 * * \\
(-2.406)\end{array}$ \\
\hline $\ln (1+\operatorname{tier} I)$ & $\begin{array}{c}0.018 \\
(1.530)\end{array}$ & $\begin{array}{c}0.018 \\
(1.531)\end{array}$ & $\begin{array}{c}0.018 \\
(1.538)\end{array}$ & $\begin{array}{c}0.022 * \\
(2.014)\end{array}$ & $\begin{array}{c}0.022 * \\
(1.972)\end{array}$ & $\begin{array}{l}0.022 * * \\
(2.071)\end{array}$ \\
\hline Municipal to tier I ratio & $\begin{array}{c}0.004 \\
(1.275)\end{array}$ & $\begin{array}{c}0.004 \\
(1.279)\end{array}$ & $\begin{array}{c}0.004 \\
(1.052)\end{array}$ & $\begin{array}{c}0.001 \\
(0.330)\end{array}$ & $\begin{array}{c}0.001 \\
(0.341)\end{array}$ & $\begin{array}{c}0.001 \\
(0.269)\end{array}$ \\
\hline Deposits held in WI to total deposits & $\begin{array}{c}0.009 * \\
(1.939)\end{array}$ & & & $\begin{array}{l}0.041 * * * \\
(10.446)\end{array}$ & & \\
\hline Deposits held in $\mathrm{OH}$ to total deposits & & $\begin{array}{c}0.002 \\
(0.596)\end{array}$ & & & $\begin{array}{c}-0.005 \\
(-1.221)\end{array}$ & \\
\hline Deposits held in 13 states to total deposits & & & $\begin{array}{c}-0.007 \\
(-1.197)\end{array}$ & & & $\begin{array}{c}-0.004 \\
(-0.564)\end{array}$ \\
\hline Constant & $-0.040 * *$ & $-0.041 * *$ & $-0.036^{*}$ & $0.050 * * *$ & $0.049 * *$ & $0.052 * * *$ \\
\hline
\end{tabular}




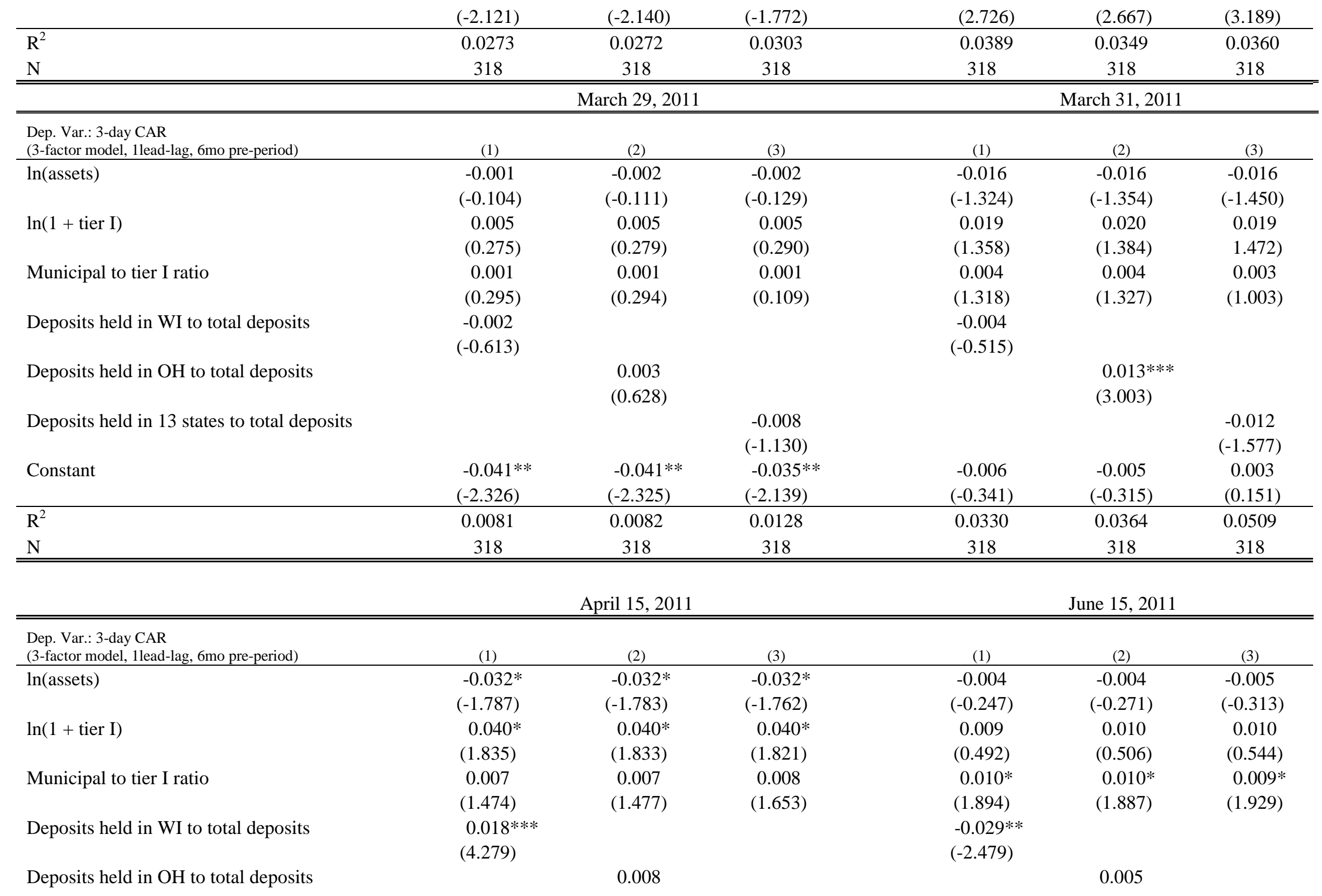




\begin{tabular}{|c|c|c|c|c|c|c|}
\hline \multirow{3}{*}{ Deposits held in 13 states to total deposits } & \multicolumn{3}{|c|}{ (1.482) } & \multicolumn{3}{|c|}{$(0.855)$} \\
\hline & & & 0.002 & & & -0.009 \\
\hline & & & $(0.211)$ & & & $(-1.148)$ \\
\hline \multirow[t]{2}{*}{ Constant } & -0.029 & -0.029 & $-0.031 * *$ & $-0.066^{* *}$ & $-0.065 * *$ & $-0.059 * *$ \\
\hline & $(-1.653)$ & $(-1.675)$ & $(-2.101)$ & $(-2.518)$ & $(-2.495)$ & $(-2.347)$ \\
\hline $\mathrm{R}^{2}$ & 0.0897 & 0.0898 & 0.0892 & 0.0372 & 0.0358 & 0.0421 \\
\hline \multirow[t]{2}{*}{$\mathrm{N}$} & 316 & 316 & 316 & 310 & 310 & 310 \\
\hline & \multicolumn{3}{|c|}{ July 21, 2011} & \multicolumn{3}{|c|}{ November 8,2011} \\
\hline \multicolumn{7}{|l|}{$\begin{array}{l}\text { Dep. Var.: 3-day CAR } \\
\text { (3-factor model, 1lead-lag, 6mo pre-period) }\end{array}$} \\
\hline \multirow[t]{2}{*}{$\ln ($ assets $)$} & 0.002 & 0.002 & 0.002 & $-0.027 * * *$ & $-0.027 * * *$ & $-0.028 * * *$ \\
\hline & $(0.196)$ & $(0.212)$ & $(0.239)$ & $(-2.847)$ & $(-2.839)$ & $(-3.136)$ \\
\hline \multirow[t]{2}{*}{$\ln (1+\operatorname{tier} I)$} & -0.001 & -0.001 & -0.002 & $0.031 * * *$ & $0.032 * * *$ & $0.033 * * *$ \\
\hline & $(-0.120)$ & $(-0.133)$ & $(-0.157)$ & $(2.959)$ & $(2.943)$ & $(3.224)$ \\
\hline \multirow[t]{2}{*}{ Municipal to tier I ratio } & -0.003 & -0.003 & -0.002 & $0.011 * *$ & $0.011 * *$ & $0.010 * *$ \\
\hline & $(-0.692)$ & $(-0.689)$ & $(-0.639)$ & $(2.517)$ & $(2.512)$ & $(2.358)$ \\
\hline \multirow[t]{2}{*}{ Deposits held in WI to total deposits } & $0.011 *$ & & & -0.004 & & \\
\hline & $(1.924)$ & & & $(-0.323)$ & & \\
\hline \multirow[t]{2}{*}{ Deposits held in $\mathrm{OH}$ to total deposits } & & -0.002 & & & 0.003 & \\
\hline & & $(-0.457)$ & & & $(0.554)$ & \\
\hline \multirow[t]{2}{*}{ Deposits held in 13 states to total deposits } & & & 0.005 & & & $-0.015^{*}$ \\
\hline & & & $(0.582)$ & & & $(-2.008)$ \\
\hline \multirow[t]{2}{*}{ Constant } & -0.011 & -0.012 & -0.015 & -0.003 & -0.003 & 0.007 \\
\hline & $(-0.466)$ & $(-0.485)$ & $(-0.620)$ & $(-0.117)$ & $(-0.105)$ & $(0.292)$ \\
\hline $\mathrm{R}^{2}$ & 0.0024 & 0.0021 & 0.0041 & 0.0535 & 0.0536 & 0.0756 \\
\hline $\mathrm{N}$ & 307 & 307 & 307 & 298 & 298 & 298 \\
\hline
\end{tabular}

